Başvuru : 02.07.2018

Kabul : :04.04.2019

\title{
Örgütsel Sinizm ve Özdeşleşme Bağlamında Algılanan Örgütsel Desteğin İşe Bağlanma ve Politik Davranış Algısına Etkisi ${ }^{1}$
}

\author{
Gökhan Kerse ${ }^{2}$ \\ Canan Nur Karabey
}

Örgütsel Sinizm ve Özdeşleşme Bağlamında Algılanan Örgütsel Desteğin işe Bağlanma ve Politik Davranış Algısına Etkisi

Öz

Bu araştırmada örgütsel destek, sinizm, özdeşleşme, işe bağlanma ve politik davranış algısı arasındaki ilişkiler ele alınmıştır. Araştırmada örgütsel desteğin sinizm aracılığıyla özdeşleşme üzerindeki etkisi ve örgütsel desteğin özdeşleşme aracılığıyla işe bağlanma ile politik davranış algısı üzerindeki etkisi incelenmiştir. Araştırmada öncelikle değişkenler arasındaki ilişkiyi ele alan araştırmalar incelenmiş ve bu doğrultuda araştırma modeli ve hipotezler oluşturulmuştur. Araştırma verileri Aksaray ilindeki 218 banka çalışanından anket tekniğiyle elde edilmiştir. Gerekli istatistiksel analizler yapıldıktan sonra örgütsel desteğin işe bağlanmaya etkisinde özdeşleşmenin kısmi aracı; politik davranış algısına etkisinde ise tam aracı rol üstlendiği gözlenmiştir. Ayrıca analizler sonucunda örgütsel desteğin özdeşleşmeye etkisinde örgütsel sinizmin de kısmi aracı rol üstlendiği görülmüştür.

Anahtar Kelimeler: Algılanan Örgütsel Destek, Örgütsel Sinizm, Örgütsel Özdeşleşme, İşe Bağlanma, Politik Davranış Algısı.
The Effect of Perceived Organizational Support on Work Engagement and Perceived Political Behavior Through Organizational Cynicism and Identification

\section{Abstract}

The aim of this study is to investigate the relationships among organizational support, cynicism, identification, work engagement and political behavior perceptions. The effect of perceived organizational support on organizational identification through the mediating role of organizational cynicism was investigated and also the effect of perceived organizational support on work engagement and political behavior perceptions via organizational identification was addressed. First, a literature review was carried out with respect to the studies associating the aforementioned variables. Later in light of the literature review a research model was developed and hypotheses were formulated. Data were gathered through a survey conducted on 218 bank employees operating in Aksaray province. After statistical analyses, it was observed that the effect of organizational support on work engagement is partially mediated by organizational identification and the effect of organizational support on political behavior perceptions is fully mediated by organizational identification. Furthermore, it was observed that the effect of organizational support on organizational identification is partially mediated by organizational cynicism.

Keywords: Perceived Organizational Support, Organizational Cynicism, Organizational Identification, Work Engagement, Political Behavior Perceptions.

\section{Giriş}

Günümüzde örgütler arasındaki rekabet geçmişe nazaran artmış, küresel örgütlerin yaygınlaşmasıyla birçok sektörde hayatta kalmak zorlaşmıştır. Bankacılık sektörü de bu zorluğun yaşandığı alanlardan biri haline gelmiştir. Nitekim günümüz bankalarında kullanılan fiziki faktörler birbirine benzemekte; verilen hizmetler de dâhil olmak üzere pazarlama ve yönetim anlayışları kolaylıkla taklit edilebilmektedir. Böyle bir ortamda bankaların başarılı olması ve bu başarının devamı, etkili ve verimli olmakla ve istenen düzeyde çıktıları elde etmekle mümkün olmaktadır. Diğer örgütlerde olduğu gibi bankalarda da etkili ve verimli olmak ve taklit edile-

\footnotetext{
${ }^{1}$ Bu çalışma ilk yazarın doktora tezi çalışmasından türetilmiştir.

2 Dr. Öğr. Üyesi, Karamanoğlu Mehmetbey Üniversitesi, iiBF, İşletme Bölümü. gokhankerse@hotmail.com, yazar ORCID bilgisi: https://orcid.org/0000-0002-1565-9110.

3 Doç. Dr., Atatürk Üniversitesi, iiBF, İşletme Bölümü. ckarabey@atauni.edu.tr, yazar ORCID bilgisi: https://orcid.org/0000-0003-0597-3605.
} 
mez yeteneklere sahip olmak insan kaynağıyla sağlanmaktadır. Bu nedenle bankacılık sektöründe faaliyet gösteren örgütlerde taklit edilebilirliği zorlaştıracak nitelikte insan kaynağı bulundurmak ve bu kaynağı kullanabilmek önem arz etmektedir. İşletmelerin en önemli kaynağı haline gelen insanın -çalışanın- örgütsel amaçlara yönelmesi ve yeteneklerini kullanabilmesi; örgütle bütünleşmesine, örgüte ait olma duygusu hissetmesine, örgütün başarısını veya başarısızlığını kişisel olarak da üstlenebilmesine ve iş yükümlülüklerini en iyi şekilde yerine getirerek işine tümüyle odaklanmasına bağlıdır. Çalışanda böyle bir psikolojik durumun oluşması, örgütün kendisine değer verdiğini ve kendisini önemsediğini hissetmesine, yani örgütsel destek algısına bağlıdır. Örgütsel destek algısının oluşması çalışanın sinik davranışlarını azaltıp örgüt ile bütünleşmesini ve birliktelik duygusu hissetmesini sağlamanın yanında politik davranış algısını azaltır ve işine tümüyle yoğunlaşmasını (işe bağlanmasını) sağlar.

Bu araştırma örgütlerin rekabet üstünlüğü sağlaması, bu üstünlüğü sürdürmesi ve yaşamlarını devam ettirmesi açısından önem taşıyan örgütsel destek, örgütsel sinizm, örgütsel özdeşleşme, işe bağlanma ve politik davranış algısı arasındaki etkileşimi ele almaktadır. Yapılan çalışmalar örgütsel desteğin sinizm, özdeşleşme, işe bağlanma ve politik davranış algısı üzerinde etkisi olduğunu öne sürmektedir; fakat bu değişkenleri birlikte ele alan ve aralarındaki etkileşimin düzeyini ve yönünü değerlendiren yeterli araştırma bulunmamaktadır. Ayrıca yapılan araştırmalar örgütsel desteğin diğer değişkenler üzerindeki etkisinin doğrudan veya dolaylı olarak ne düzeyde gerçekleştiğini açıklamada yetersiz kalmaktadır. Çalışanın işine bağlanmasında ve örgüt içi politik davranış algısında hangi değişkenlerin daha önemli olduğunun belirlenmesi ve bu değişkenlere dolaylı olarak etki eden değişkenlerin tespit edilmesi gerekmektedir. Nitekim çalışanın işine tümüyle yoğunlaşarak yeteneklerini ortaya koymasında ve iş yükümlülüklerini istekli bir şekilde yerine getirmesinde tek bir örgütsel faktör yeterli değildir. Ayrıca çalışanın örgütte kişisel çıkarlar yerine ortak çıkarların önde tutulduğuna ilişkin düşüncesi örgütün amaçlarına ulaşmasında önem arz ettiğinden, politik davranış algısını hangi değişkenlerin doğrudan, hangilerinin ise dolaylı olarak etkilediğini belirleme ihtiyacı doğmuştur. Bu sorunsala araştırmada kısmen de olsa cevap aranmaya çalışılmıştır. Bu nedenle bu araştırmada işe bağlanma ve politik davranış algısını doğrudan ve dolaylı olarak etkileyen faktörlerden bazıları ele alınmıştır. Araştırma örgütsel desteğin özdeşleşmeye etkisinin sinizm aracılığıyla gerçekleşip gerçekleşmediğini ve örgütsel desteğin işe bağlanma ve politik davranış algısını özdeşleşme vasıtasıyla etkileyip etkilemediğini incelemiştir.

\section{Teorik Çerçeve ve Hipotezler}

\subsection{Algılanan Örgütsel Destek}

Örgütsel davranış alanında algılanan örgütsel destek kavramı Eisenberger ve arkadaşlarının (1986) çalışmasında kullanılmıştır. Eisenberger ve arkadaşları, algılanan örgütsel desteği örgütün çalışan refahını, mutluluğunu ve katkısını ne düzeyde önemsediğine ilişkin çalışan algısı ve inancı olarak tanımlamışlardır. Öte yandan Wann-Yih ve Htaik (2011) algılanan örgütsel desteği örgütün çalışanın çabasını dikkate alması ve çalışanın iyiliğini önemsemesine ilişkin çalışan bakış açısı olarak tanımlarken; Dawley vd. (2010) örgütte çalışanın performansının ödüllendirilmesi ve sosyo-duygusal ihtiyaçlarının karşılanmasına ilişkin çalışan görüşleri olarak açıklamıştır. Tanımlar incelendiğinde ortak noktanın, örgütsel destek algısının çalışan katkısına değer verilip verilmediği, mutluluğunun önemsenip önemsenmediği ve ihtiyaçlarının karşılanıp karşılanmadığına ilişkin algısal bir oluşumu yansıttığı söylenebilir.

Algılanan örgütsel destek kavramının ortaya çıkıp gelişmesini sağlayan iki önemli basamak vardır. Bu basamaklardan birisi Gouldner (1960) tarafından öne sürülen "karşlıklılık normu 
teorisi", bir diğerini ise Blau (1964) tarafından öne sürülen "sosyal değişim teorisi"dir. Karşılıklılık normu teorisine göre bireylerin kendilerine yardım eden bireylere, bu davranışları karşılığında yardım etmesi gerektiğini öne sürer (Shelton, 2013). Dolayısıyla karşlıklılık normuna göre, örgütün çalışana faydalı davranışlar sergilemesi çalışanın da örgütüne olumlu yönde tepki vermesini yükümlü kılmaktadır.

Algılanan örgütsel destek, temeli karşılıklılık normu teorisine dayanan Blau'nun (1964) geliştirdiği sosyal değişim teorisi bakış açısıyla, işverenler ve çalışanlar arasındaki ilişkiyi açıklar (Baran vd., 2012). Bu ilişkinin temelini hem çalışana hem de örgüte fayda sağlayacak faaliyetler oluşturur (Eisenberger vd. 1986). Örgüt, bünyesindeki çalışanın katkısına değer verip iyiliğini düşündüğüne yönelik örgütsel uygulamalar gerçekleştirecek; çalışan da, bu uygulamalar karşısında örgütün amaçlarına ulaşabilmesi için çaba sarf etmesi gerektiği yönünde büyük bir yükümlülük hissedecektir (Eisenberger vd. 1990). Ortaya çıkan bu yükümlülük de çalışanın örgüte yönelik olumlu tutum ve davranışlar sergilemesini sağlayacaktır (Aselage ve Eisenberger, 2003). Bu şekilde çalışan ve örgüt birlikte çıkar ve faydalarını sağlayacak şekilde sosyal değişime katıldıklarında, algılanan örgütsel desteğin sonuçları da daha etkili olacaktır.

\subsection{Algılanan Örgütsel Destek ve İşe Bağlanma Arasındaki iliş̧ki}

İşe bağlanma, çalışanların kendilerine verilen işi yapmaya hazır olduklarını hissetmesi ve iş yükümlülüklerini yerine getirmeye istekli olmasıdır (Schaufeli vd. 2006). Bazı araştırmacılar bu tanımı bir adım ileriye taşıyarak kavramı "işe yönelik bir tutkuya sahip olma durumu" olarak ifade ederken (Shorbaji vd. 2011), diğer bazıları kavramı motivasyonel olarak ele almış (Leiter ve Bakker, 2010) ve işe bağlanmayı çalışanların işlerine tümüyle yoğunlaşmalarıyla, çalışma saatlerinin hızlı bir şekilde geçmesini sağlayan motivasyonel ruhsal durum olarak tanımlamışlardır (Bakker vd. 2008).

İşe bağlanma çalışanların işle ilgili olarak diğer çalışanlarla etkileşimde bulunma ve iş rollerini yerine getirmede çaba harcama ve iş rollerine bilişsel, duygusal ve davranışsal olarak bağlanma düzeyidir (Ferrer 2005). Bu durum çalışanın görevlerine yönelik güçlü psikolojik bağlıığını göstermektedir (Biggs vd. 2014). Ayrıca işe bağlanma canlılık, adanma ve yoğunlaşmayı içeren işe yönelik olumlu, tatmin edici ruhsal durumu da ifade etmektedir (Schaufeli ve Bakker, 2004); çünkü bağlanma düzeyi yüksek çalışanlar işlerini yerine getirirken oldukça enerjik bir şekilde iş gereklerinin üstesinden gelebilmektedirler (Taris vd. 2010). Ayrıca işine bağlanan çalışanlar çok dikkatli olmakta ve zor sorunların altında yatan nedene odaklanarak çözüm aramaktadır (Leiter ve Bakker, 2010).

Örgütsel destek algısı ile işe bağlanma arasındaki ilişkiyi karşılıklılık normuna dayalı olarak açıklamak mümkündür. Gouldner'ın (1960) "karşılıklılık normu” çerçevesinde değerlendirildiğinde, örgütün çalışana verdiği destek çalışanın da örgütün faydasına yönelik davranışlar sergilemesi yükümlülüğünü doğuracaktır. Diğer bir ifadeyle örgütün çalışanın beklentilerini dikkate alması ve ihtiyaçlarını karşılaması çalışanda da örgütü önemseme ve olumlu davranışlar sergileme yükümlülüğünü ortaya çıkaracaktır. Dolayısıyla çalışan örgütün amacının başarıya ulaşması için daha fazla çaba sarf edecek, verilen işi daha istekli şekilde yapacak ve işine bağlanacaktır. Nitekim Shantz ve arkadaşlarının (2016) yaptıkları araştırmada örgütsel destek ile işe bağlanma arasında pozitif yönlü bir ilişki olduğu belirlenmiştir. Saks (2006); Rich ve arkadaşları (2010); Kim (2012); Caesens ve Stinglhamber (2014); Gillet ve arkadaşları (2013) araştırmalarında örgütsel desteğin işe bağlanmayı pozitif yönde ve anlamlı düzeyde etkilediği bulgusunu elde etmişlerdir. Örgütsel desteğin işe bağlanma üzerindeki söz konusu etkisi yakın geçmişte yapılan bazı araştırma sonuçlarıyla da desteklenmiştir (Gupta vd. 2016; Karatepe ve Aga, 
2016; Jin ve McDonald, 2016; İnce, 2016). Bu görüşlerden hareketle aşağıdaki hipotez geliştirilmiştir:

$H_{1}$ : Çalışanların algıladığı örgütsel destek işe bağlanma düzeylerini olumlu yönde ve anlamIı düzeyde etkiler.

\subsection{Algılanan Örgütsel Destek ve Politik Davranış Algısı Arasındaki İlişki}

Politik davranış, örgütsel yaşamda her zaman var olan ve örgüt davranışlarını yönlendiren bir kavramdır (Ferris vd., 1989; Ferris ve Judge, 1991) ve kavram araştırmacılar tarafından farklı şekillerde ele alınmıştır. Literatürde her ne kadar kavrama ilişkin çok fazla tanım bulunsa da, Cropanzona ve arkadaşlarına (1997) göre genel kabul gören iki farklı bakış açısı vardır. Araştırmacılara göre bunlardan ilki, politik davranışı iş ortamında uygulanan bir etkileme süreci olarak görür ve örgütün işlerliğine katkı sağlayan "etkili bir sosyal araç" olduğunu öne sürer. Bu bakış açısıyla ele alındığında politik davranışın koşullara bağlı olarak, hem işlevsel hem de işlevsel olmayan sonuçlar doğurması mümkündür (Ferris vd. 1989). Politik davranışın örgütün çıkarlarına hizmet etmesi işlevsel olduğunu gösterirken, bireyin çıkarlarına hizmet etmesi işlevsel olmadığı anlamına gelmektedir (Landells ve Albrecht, 2013).

Politik davranış kavramına ilişkin ikinci bakış açısı, kavramı diğerlerinin amaçları ve çıkarlarıyla çatışan ve kişisel çıkarları artırmak üzere gerçekleştirilen davranışlar kapsamında ele alır (Evans ve Qureshi, 2013). Bu açıdan değerlendirildiğinde politik davranış, bir bireyin örgütteki diğer bireylerin çıkarlarını düşünmeden kendi çıkarları için çaba sarf etme ve bu doğrultuda kısa ve uzun dönemli hedeflerine ulaşmaya çalışma gayretidir. Bu çalışmada politik davranış kavramı ikinci bakış açısıyla ele alınmıştır.

Politik davranış kavramı sergilenen politik davranışlar ve algılanan politik davranışlar (politik algılar) olmak üzere iki farklı kısımda incelenmelidir. Sergilenen politik davranış, bireylerin diğer bireylerin çıkarları pahasına kişisel çıkarlarını en yüksek düzeye çıkarmak için sergilediği davranışlardır (Ferris vd. 1989). Politik algı veya politik davranış algısı ise, bireylerin iş çevrelerinin kişisel çıkarları ne düzeyde teşvik ettiğini ve adaletsizliğin ne düzeyde olduğunu kişisel olarak değerlendirmesidir (Vigoda ve Cohen, 2002). Bu nedenle örgütteki mevcut politik davranış ile bu davranışın politik olarak algılanması arasında farkın ortaya çıkması mümkündür.

Örgütsel destek ile politik davranış algısı arasındaki ilişki Blau’nun (1964) "sosyal değişim teorisi" bakış açısından da ele alınabilir. Sosyal değişim, ikili ilişkilerin bireylerin kişisel faydalarını en yüksek düzeye çıkarmak için gerçekleştiğini öne süren teoridir (Aselage ve Eisenberger, 2003). Teoriye göre bireyler arasındaki etkileşimin sağlanması ve devamı karşılıklı değer verilen şeylerin değiştirilmesine bağııdır. Diğer bir ifadeyle bireyler hem kendi aralarında hem de örgüt ile ilişkilerinde katlandıkları maliyetin karşılığında elde ettikleri faydaları değerlendirmektedir. Bu doğrultuda örgütsel amaçlara ulaşmada çalışanın sarf ettiği çaba ve harcadığı zamanın, onun faydasına yönelik olarak para, bazı hizmetler ve takdir gibi kaynaklarla karşılık bulması gerekmektedir. Eğer harcadığı zaman ve sarf ettiği çaba, para ve diğer karşılıklarla ödüllendirilmemiş ise ya da ödüllendirilme gerçekleşmiş fakat onun beklentisini karşılamamış ise bu durum örgütün çalışanı önemsemediği ve hem örgütün hem de örgüt temsilcilerinin kişisel çıkarlarını düşündüğü algısını oluşturacaktır. Dolayısıyla örgütün kendisini desteklemediği inancına sahip olan çalışan örgütte politik davranışların sergilendiğini düşünecektir. Yapılan ampirik araştırmalarda da bu görüşü destekleyen sonuçlara ulaşılmıştır. Cropanzano ve arkadaşları (1997), Randall ve arkadaşları (1999), Lee ve Peccei (2011); Andrews ve Kacmar (2001); Bukhari ve Kamal (2015) ve Sides (2013) yaptıkları araştırmalarda örgütsel destek ile 
politik davranış algısı arasında olumsuz yönde bir ilişki olduğu bulgusunu elde etmişlerdir. Kavramlar arasındaki ilişkiyi inceleyen bu araştırmaların yanında Harris ve arkadaşları (2007) araştırmalarında örgütsel desteğin politik davranış algısını negatif yönde ve anlamlı düzeyde etkilediği sonucuna ulaşmışlardır. Bu açıklamalar ve araştırma bulguları çerçevesinde örgütsel destek ve politik davranış algısı arasındaki ilişkiye yönelik aşağıdaki hipotez oluşturulmuştur:

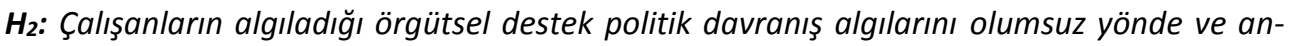
lamlı düzeyde etkiler.

\subsection{Algılanan Örgütsel Destek ve Örgütsel Özdeşleşme Arasındaki Iliş̧ki}

Özdeşleşme bireyin üyesi olduğu örgütle kendisini tanımlayabilmesi ve örgütle aidiyet bağı olduğunu hissedebilmesidir. Özdeşleşme kavramının bu anlamıyla günümüzde kullanılması 1970 lerden sonra yapılan araştırmalarda görülmüştür. O yıllardan bu yana kavrama daha fazla önem verilmiş ve farklı tanımlarla araştırmalarda kullanılmıştır. Örneğin Patchen (1970) kavramı "örgüt ile birlik olma, örgütsel amaçları destekleme ve örgüt üyeleriyle ortak değerleri paylaşma" şeklinde üç unsur ile açıklamıştır. Hall ve arkadaşları (1970) örgütle özdeşleşme kavramını bireyin amaçlarıyla örgütün amaçlarının bütünleşmesi ve bu amaçların uyumlu hale gelmesi olarak tanımlarken; Buchanan (1974) örgütsel amaçları gerçekleştirmede ve örgüt değerlerini hayata geçirmede bireyin üstlendiği rolü gereğince yerine getirebilmesi şeklinde ifade etmiştir. Zira örgüt ile özdeşleşmenin gerçekleşmesiyle birey örgütsel amaçların başarıya ulaşmasında daha fazla çaba sergilemektedir.

Örgütsel özdeşleşme, çalışanların örgütlerini tarif ederken kullandıkları ifadeleri kendilerini tarif ederken de kullanabilmesidir (Dutton vd., 1994); çünkü örgütü ile özdeşleşen bir çalışanın örgütünü tarif ederken kullandığı ifadeler aynı zamanda kendisini tarif ederken kullandığı ifadelerdir. Bir diğer ifadeyle örgütüyle özdeşleşmiş bir çalışan örgütünün özelliklerini kendi kişisel özellikleri olarak benimsemektedir.

Örgütsel özdeşleşmeye ilişkin en fazla kabul gören tanımlardan birisi Ashforth ve Mael (1989) tarafından yapılmıştır. Ashforth ve Mael (1989) kavramı birliktelik ve ait olma duygusu açısından değerlendirmiştir. Araştırmacılara göre özdeşleşme bireyin üyesi olduğu örgüte aidiyet veya birliktelik hissetmesi ve örgütün başarı ve başarısızlığını kişisel olarak üstlenmesidir (Ashforth ve Mael, 1989). Bu tanımdan hareketle özdeşleşmenin çalışanın üyesi olduğu örgütü benimseyebilmesini ve ona bağlanabilmesini de içerdiği söylenebilir.

Örgütsel destek ile örgütsel özdeşleşme arasındaki ilişki Blau'nun (1964) "sosyal değişim teorisi" ve Gouldner'ın "karşılıklılık normu" doğrultusunda açıklanabilir. Sosyal değişim teorisinin bakış açısı ele alındığında; çalışanın örgütsel amaçları başarmak için sarf ettiği çaba ve harcadığı zaman, örgütün kendisine sunduklarıyla (para, takdir vb. gibi maddi ve sosyal ihtiyaçlar) değiştirilmektedir. Bu değişim ilişkisinde çalışan sarf ettiği çaba ve harcadığı zaman karşılığında örgütte kendisinin iyiliğinin ve refahının düşünüldüğünü ve gerek maddi gerekse sosyal ihtiyaçlarının beklediği düzeyde karşılandığını algılarsa örgüt için olumlu olan ve örgütsel fayda yaratan davranışlar sergileyecektir. Bir diğer ifadeyle; karşlıklıık normu doğrultusunda tarafların memnun olacağı ve karşılıklı etkileşimin devam edeceği bir değişim faaliyeti sağlanmış olacaktır. Dolayısıyla çalışan hem üyesi olduğu örgüt hem de üyesi olduğu örgütün temsilcileri ile gerçekleştirdiği değişim ilişkisinin kaliteli olduğuna inanırsa kendisini örgüt üyeliği ile daha fazla tanımlayacak (van Knippenberg vd. 2007) yani üyesi olduğu örgüt ile daha fazla özdeşleşecektir (Nartgün ve Kalay, 2015). Nitekim yazındaki ampirik çalışma bulguları da bu beklentiyi destekler niteliktedir. Örneğin Çelik ve Findik'in (2012); Sökmen ve arka- 
daşlarının (2015); van Knippenberg ve arkadaşlarının (2007); Cho ve Treadway'in (2016) yaptıkları araştırmalarda örgütsel destek ve özdeşleşme arasında olumlu ve anlamlı bir ilişki olduğu görülmüştür. Cheung ve Law (2008); Sluss ve arkadaşları (2008); Zagenczyk ve arkadaşları (2011); Turunç ve Çelik (2010); He ve arkadaşları (2014) ve Ertürk (2010) yaptıkları araştırmalarda örgütsel desteğin özdeşleşmeyi olumlu yönde etkilediğini belirlemişlerdir. Bu açıklama ve araştırma bulguları doğrultusunda aşağıdaki araştırma hipotezi geliştirilmiştir:

$H_{3}$ : Çalışanların algıladığı örgütsel destek örgütle özdeşleşme düzeylerini olumlu yönde ve anlamlı düzeyde etkiler.

\subsection{Algılanan Örgütsel Destek ve Örgütsel Sinizm Arasındaki İlişki}

Sinizmi “bireylerin açığa vurulmamış amaçları hakkında kötümser olması ve hayal kırıklığına dayalı olarak olayları açıklaması ve kişisel çıkarlarını artırmak için araç olarak başkalarıyla ilgilenmesi" şeklinde tanımlanan olumsuz bir tutum olarak değerlendirmek mümkündür (Eryeşil ve Fındık, 2011). Bu olumsuz tutum kişilere, gruplara, ideolojilere veya sosyal düzene karşı olabileceği gibi (Andersson 1996) kurumlara ya da örgütlere karşı da sergilenebilir. Sinizmin bir kuruma veya örgüte karşı sergilendiği bu şekli örgütsel sinizm olarak ifade edilir. Örgütsel sinizm, çalışanın örgütün dürüstlükten yoksun olduğunu düşünmesi durumunda kendisini göstermekte (Karacaoğlu ve İnce, 2012) ve çalışanın üyesi olduğu örgüte güvenmemesi, onu küçümsemesi ve örgüte yönelik umutsuzluk ve hayal kırıklığı yaşaması durumu olarak tanımlanmaktadır (Andersson, 1996). Dolayısıyla örgütsel sinizm “örgütün bütünlükten ve dürüstlükten yoksun olduğu inancı"nın bir sonucudur (Johnson ve O'leary-Kelly, 2003). Yani örgüt üyesi örgütsel faaliyetleri kişisel inançları doğrultusunda değerlendirmekte ve uyumsuzluk algılanması durumunda örgütün dürüst olmadığı düşünülmekte ve sinizm ortaya çıkmaktadır.

Örgütsel sinizme ilişkin birçok tanım bulunmasına rağmen yazında en çok benimsenen Dean ve arkadaşlarının (1998) tanımlamasıdır. Araştırmacılara göre örgütsel sinizm; örgütün bütünlük eksikliğine sahip olduğu inancını (bilişsel boyut), çalışılan örgüte ilişkin olumsuz duyguları (duygusal boyut) ve örgüte karşı sergilenen küçümseyici ve eleştirel davranışları (davranışsal boyut) ifade eder. Dolayısıyla örgütsel sinizmin inançların, olumsuz duyguların ve küçümseyici ve eleştirel davranışların bir bütünü olduğu söylenebilir.

Kavrama ilişkin buraya kadar yapılan açıklamalar doğrultusunda örgütsel sinizmin inançlardan, duygulardan ve davranışsal eğilimlerden ortaya çıkan çok boyutlu bir olgu olduğu söylenebilir. Birey bilişsellik sürecinde üyesi olduğu örgütün dürüst olmadığını düşünürken; duygusallık sürecinde örgüte karşı sinirlilik, küçümseme ve utanma gibi bazı duygularla tepki vermekte; davranışsalık sürecinde ise artık duygu ve düşünceler olumsuz davranışlara dönüşmektedir. Bu nedenle örgütsel sinizmi çalışanın örgüte yönelik olumsuz düşüncelerinin, güçlü olumsuz duygularla bir araya gelmesi sonucunda örgütü küçümseyici ve kötüleyici davranışlar sergilemesi olarak tanımlamak mümkündür.

Örgütsel destek algısı ile örgütsel sinizm arasındaki ilişkiyi de sosyal değişim teorisiyle açıklamak mümkündür. Daha önce de ifade edildiği gibi sosyal değişim bakış açısı örgütsel destek kavramının temelini oluşturan ve gelişmesini sağlayan basamaklardan biridir. Örgütsel destek örgütsel fayda sağlamaya ilişkin sergilenen davranışları ve tutumları içerir. Örgütsel desteğin algılanmasıyla çalışan ve örgüt arasında karşılıklı değişim faaliyeti gerçekleşir ve her iki tarafın da birbirlerine fayda sağlayacağı davranışlar sergilenir. Değişim ilişkisinin beklentiler doğrultusunda gerçekleşmesi tarafların etkileşiminin sürdürülmesini sağlar. Değişim ilişkisinde örgüt çalışanı dikkate alır ve çalışanın ihtiyaçlarını karşılar ise çalışan da örgüt çıkarlarına uygun dav- 
ranışlar sergiler. Çalışanın hem maddi hem de sosyo-duygusal ihtiyaçlarının göz ardı edilmesi ve beklentilerinin karşılanmaması ise örgüte karşı sergilenen sinik davranışları artırır (Byrne ve Hochwarter, 2008). Bir diğer ifadeyle gerek yönetimin gerekse örgütün kendisine değer vermediğini düşünen çalışanın ör güte ve yöneticilere güvenmeme, örgütün dürüstlükten yoksun olduğuna inanma ve örgütü aşağılayıcı davranışlarda bulunma eğilimi yüksek olur. Nitekim Brandes (1997) ve Byrne ve Hochwarter (2008) yaptıkları araştırmalarda örgütsel destek ile sinizm arasında ters yönde bir ilişki olduğunu belirlemişlerdir. Treadway ve arkadaşlarının (2004), Tokgöz'ün (2011) ve James'in (2005) yaptıkları araştırmalarda örgütsel desteğin sinizm üzerinde olumsuz yönde ve anlamlı düzeyde bir etkisinin olduğu görülmüştür. Chiaburu ve arkadaşları (2013) yaptıkları meta-analiz çalışmasında da benzer bulgular elde etmiştir. Söz konusu açıklama ve ampirik araştırmalar doğrultusunda aşağıdaki araştırma hipotezi geliştirilmiştir:

$H_{4}$ : Çalışanların algıladığı örgütsel destek sinizm düzeylerini olumsuz yönde ve anlamlı düzeyde etkiler.

\section{6. Örgütsel Özdeşleşme ve İşe Bağlanma Arasındaki İlişki}

Örgütle özdeşleşme çalışanın amaçlarıyla örgütün amaçlarının uyumlu olması ve çalışanın örgütü iyi veya kötü gününde sahiplenmesi durumudur. Örgütüyle özdeşleşmiş bir çalışan örgütsel başarı ve başarısızlığı kişisel olarak üstlenerek kendisini örgütün bir parçası olarak görür ve örgütle psikolojik bir bağ kurar. Kurulan bu bağ örgüte ilişkin daha olumlu tutumlar sergilemenin yanında (Dutton vd. 1994) örgütsel amaçları içselleştirme ve bu amaçlara ulaşmak için daha fazla çalışılma ile sonuçlanır (Karanika-Murray vd. 2015). Ayrıca örgütüyle özdeşleşen çalışan işine gönüllü olarak katılır ve örgütün çıkarlarını kişisel çıkarlarından daha fazla ön planda tutar (Dutton vd. 1994). Özdeşleşen çalışanların görev tanımlarının ötesinde performans sergilemesi ve hem fiziksel hem de bilişsel olarak işlerine daha fazla yoğunlaşması, yani işlerine bağlanması beklenir (Gözükara ve Şimşek, 2016). Dolayısıyla kendisini tanımlarken çalıştığı örgütü vurgulayan ve onun bir parçası olarak gören çalışan tümüyle işlerine yoğunlaşma ve bağlanma eğilimindedir. Yapılan ampirik araştırmaların sonuçları da bu görüşü desteklemektedir. Chughtai ve Buckley (2009); Demirtas ve arkadaşları (2015); Guarana (2010); He ve arkadaşları (2013) araştırmalarında çalışanın özdeşleşme düzeyi arttıkça işe bağlanma düzeyinin de arttığı bulgusunu elde etmiştir. Gözükara ve Şimşek'in (2016); Ötken ve Erben'in (2010); Karanika-Murray ve arkadaşlarının (2015) yaptıkları araştırmalarda örgütle özdeşleşmenin işe bağlanmayı pozitif yönde ve anlamlı düzeyde etkilediği görülmüştür. Bu açıklamalardan ve ampirik araştırma bulgularından hareketle aşağıdaki hipotez geliştirilmiştir:

$\boldsymbol{H}_{5}$ : Çalışanların örgütleriyle özdeşleşmesi işe bağlanma düzeylerini artırır.

\section{7. Örgütsel Özdeşleşme ve Politik Davranış Algısı Arasındaki ilişki}

Literatür incelendiğinde örgütsel özdeşleşme ile politik davranış algısı arasındaki ilişkiyi doğrudan ele alan araştırmaların oldukça sınırlı sayıda olduğu söylenebilir. Ancak örgütsel başarı ve başarısızlığı kişisel olarak üstlenerek kendisini örgütün bir parçası olarak görmeyen ve örgütle psikolojik bir bağ kurmayan çalışanların örgütte politik davranış algılaması beklenebilir. Nitekim Basar ve Filizöz (2015), Başar ve Basım (2015) ve Erkutlu ve Chafra (2016) araştırmalarında özdeşleşme ve politik davranış algısı arasındaki doğrudan ilişkiye odaklanmamakla birlikte, bu değişkenler arasında olumsuz ve anlamlı bir ilişki olduğunu öne sürmüşlerdir. Başar ve arkadaşları (2015) ise araştırmalarında örgütsel özdeşleşmenin politik davranış algısının bir sonucu olduğunu belirtmişlerdir. 
Yukarıdaki araştırmalar doğrultusunda bu çalışma örgütsel özdeşleşmenin politik davranış algısını olumsuz yönde etkileyeceğini öne sürmektedir. Çünkü örgütsel amaçları ve değerleri kişisel olarak benimseyen ve örgüt ile bütünleşen çalışanlar örgütte ilişkilerin kişisel çıkarlar uğruna kurulmadığını ve örgüt ortamının adaletli olduğunu düşünür. Diğer bir ifadeyle örgütüyle özdeşleşmiş bir çalışan örgüt faaliyetlerini ve örgüt üyelerinin davranışlarını politik olarak değerlendirmez. Dolayısıyla da politik davranış algısı düşük olur. Söz konusu açıklamalardan yola çıkılarak aşağıdaki hipotez geliştirilmiştir:

H6: Çalışanların örgütle özdeşleşmesi politik davranış algılarını olumsuz yönde etkiler.

\section{8. Örgütsel Sinizm ve Özdeşleşme Arasındaki iliş̧i}

Örgütsel sinizm çalışanın örgüt hakkındaki olumsuz duygu ve düşüncelerini ifade ederken; özdeşleşme tam aksine örgütsel faydayı sağlayan olumlu tutum ve davranışları içermektedir. Çünkü sinik bir çalışan örgütün kendi çıkarları uğruna dürüstlükten ve adaletten uzaklaşabileceğini varsaymakta, bu nedenle de örgüte olumsuz duygular beslemekte ve örgütü küçümseyici davranışlar sergilemektedir. Fakat örgütüyle özdeşleşen çalışan ise birliktelik hissetmekte, örgütün değerlerini benimsemekte, onunla dayanışma içinde olmakta ve örgüt amaçlarına ulaşmayı istemektedir. Dolayısıyla sinik çalışanın örgütün değer ve amaçlarıyla kişisel değer ve amaçlarını farklı görmesi ve aidiyet duygusunun azalması beklenir. Literatürde bu değişkenler arasındaki ilişkiyi inceleyen araştırmalar bulunmaktadır ancak bunlar az sayıdadır. Polat ve Meydan (2010) yaptıkları araştırmada örgütsel özdeşleşmenin sinizm üzerinde olumsuz bir etkisinin olduğu bulgusunu elde etmiştir. Bedeian (2007) ise araştırmasında örgüte karşı sergilenen olumsuz tutum ve davranışların örgüt ile özdeşleşmeyi azalttığını belirlemiştir. Bu açıklamalardan ve ampirik araştırmalardan hareketle aşağıdaki hipotez geliştirilmiştir:

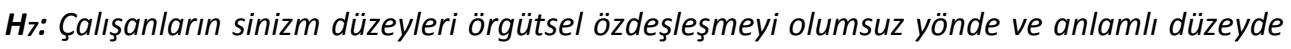
etkiler.

\subsection{Algılanan Örgütsel Desteğin İşe Bağlanma ve Politik Davranış Algısı Üzerindeki Etki-} sinde Örgütsel Özdeşleşmenin Rolü

Yukarıda ifade edildiği gibi üyesi olduğu örgütün destekleyici olduğunu düşünen çalışanların işine bağlanma derecesi artar. Ayrıca örgütten ve örgüt temsilcilerinden destek gören çalışanın örgüte aidiyet duyması ve örgütüyle özdeşleşmesi de beklenir. Nitekim örgütsel desteğin hem özdeşleşmeyi (Shen vd. 2014; Turunç ve Çelik, 2010; Zagenczyk vd. 2011) hem de işe bağlanmayı olumlu olarak etkilediğini tespit eden araştırmalar mevcuttur (Gupta vd. 2016; Karatepe ve Aga, 2016). Öte yandan örgütüyle özdeşleşen ve bütünleşen çalışanların işlerine daha fazla bağlanması beklenir (Gözükara ve Şimşek, 2016; He vd. 2013; KaranikaMurray vd. 2015). Buradan hareketle örgütsel desteğin işe bağlanmaya etkisinde özdeşleşmenin aracı rol üstlendiği ifade edilebilir. Örgütte destek algılayan çalışanın örgüt ile özdeşleşeceği; örgüt ile özdeşleşen çalışanın da işine daha fazla bağlanacağı öne sürülebilir.

Örgütün çalışanın ihtiyaçlarını karşılaması ve çalışanı desteklemesi örgütte kişisel çıkarlar uğruna politik davranışlar sergilendiği düşüncesini azaltmaktadır (Harris vd. 2007). Örgütte politik davranış algısını azaltan bir diğer değişken ise çalışanın örgütüyle birliktelik hissetmesi yani özdeşleşmesidir (Başar ve Basım, 2015). Örgütün kendisini önemsediğini ve desteklediğini algılayan çalışanın örgütüyle özdeşleştiği, bunun sonucunda da örgüt ortamında politik davranışları daha az algıladığı söylenebilir. Literatür incelendiğinde örgütsel desteğin işe bağlanmaya ve politik davranış algısına etkisinde özdeşleşmenin aracı rol oynadığını öne süren araştırmanın yapılmadığı görülmüştür. Öte yandan örgütsel özdeşleşmenin farklı değişkenler arasın- 
daki ilişkide aracı rol üstlendiğini belirten araştırmalar yapılmıştır (He vd. 2013; Gözükara ve Şimşek, 2016). Bu açıklamalar doğrultusunda aşağıdaki hipotezler oluşturulmuştur:

H8: Çalışanların örgütsel destek algısının işe bağlanma düzeyleri üzerindeki etkisinde özdeşleşme aracı rol oynar; destek algısı çalışanın özdeşleşme düzeyini artııır, bunun sonucunda da çalışanın işe bağlanma düzeyi artar.

$\boldsymbol{H}_{9}$ : Çalışanların örgütsel destek algısının politik davranış algıları üzerindeki etkisinde özdeşleşme aracı rol oynar; destek algısı çalışanın özdeşleşme düzeyini artırır, bunun sonucunda da çalışanın politik davranış algısı azalır.

\subsection{0.Örgütsel Desteğin Örgütsel Özdeşleşme Üzerindeki Etkisinde Örgütsel Sinizmin Rolü}

Çalışanların örgütlerinde destek algılaması onların örgüte karşı olumsuz tutumlarını ve örgütü aşağılayıcı davranışlarını (sinizmi) azaltırken (Chiaburu vd. 2013; Kasalak ve Aksu, 2014), örgüte ait olma hissini yani özdeşleşme düzeylerini artırmaktadır (Gillet vd. 2013; Zagenczyk vd. 2011). Öte yandan üyesi olduğu örgüte karşı sinik olan çalışanların örgütü tasvir ettikleri özelliklerle kendilerini tasvir etmemesi ve örgüte karşı ait olma duygusunu hissetmemesi beklenir (Bedeian, 2007). Dolayısıyla örgütün yeterli düzeyde destek sağladığını algılayan çalışanların örgütlerine karşı sinik tutum ve davranışları azalacak, nihayetinde de örgüt ile özdeşleşmesi kolaylaşacaktır. Diğer bir ifadeyle; örgütsel destek algısının özdeşleşme üzerindeki olumlu etkisinde sinizm aracı rol üstlenecektir. Yazında her ne kadar söz konusu değişkenleri birlikte ele alan bir araştırmaya ulaşılamasa da sinizmin farklı değişkenler arasındaki ilişkide aracılık rolünün bulunduğunu öne süren araştırmalar mevcuttur (James, 2005; Treadway vd. 2004). Söz konusu açıklamalardan hareketle aşağıdaki hipotez oluşturulmuştur:

$H_{10}$ : Çalışanların örgütsel destek algısının örgüt ile özdeşleşme düzeyi üzerindeki etkisinde sinizm aracı rol oynar; desteğin algılanması çalışanın sinizm düzeyini azaltır, bunun sonucunda da çalışanın özdeşleşme düzeyi artar.

Yukarıdaki oluşturulan hipotezler doğrultusunda Şekil 1'deki araştırma modeli oluşturulmuş ve hipotezlerin testi bu model doğrultusunda yapılmıştır.

Şekil 1: Araştırmanın Modeli

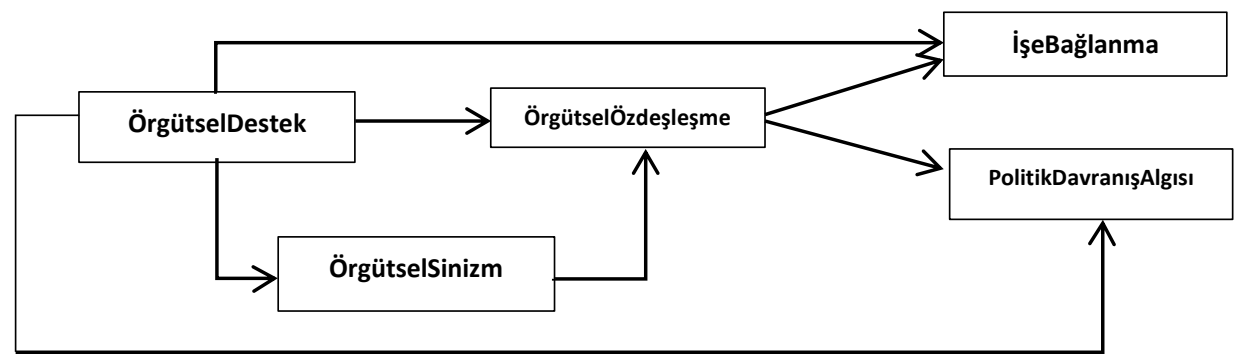




\section{Araştırmanın Yöntemi}

\subsection{Araştırmanın Amacı ve Örneklemi}

Bu araştırmada bankacılık sektöründe örgütsel destek algısının işe bağlanma ve politik davranış algısı üzerindeki etkisi ve bu etkide örgütsel sinizmin ve özdeşleşmenin rolü incelenmiştir. Bu doğrultuda araştırma "Çalışanın üyesi olduğu örgütten destek algılaması işe bağlanma ve politik davranış algısını ne düzeyde etkiler? Örgütsel destek algısı çalışanların özdeşleşme düzeylerini etkiler mi? Örgütsel desteğin işe bağlanmaya etkisinde örgütsel özdeşleşmenin rolü nedir? Destek algısıyla özdeşleşme arasındaki etkileşime sinizmin etkisi var mıdır? " gibi soruları cevaplamaya çalışmıştır.

Araştırmanın ana kütlesini Aksaray ilinde faaliyet gösteren bankalardaki çalışanlar oluşturmuştur. Sektörün yoğun çalışma temposu gerektirmesi araştırmadaki örgütsel destek, örgütsel özdeşleşme, örgütsel sinizm, politik davranış algısı ve işe bağlanma değişkenlerini ve bu değişkenlerin ilişkilerini bu sektördeki çalışanlar açısından değerlendirme yapmaya yöneltmiştir. Öte yandan bankacılık sektörünün ülkemizde yoğun rekabetin yaşandığı sektörlerden olması ve Türkiye Bankalar Birliğinin 2015 yılı verilerine göre ülkemizde 200.440 çalışana istihdam sağlaması da araştırmanın bu sektörde yapılmasının bir diğer nedenidir. Söz konusu sektörde verilerin toplanmasında anket tekniği tercih edilmiştir. Zaman, maliyet ve ulaşılabilirlik kısıtları nedeniyle anket uygulaması bizzat araştırmacı tarafından yapılmış, bu nedenle de anakütleyi sadece araştırmacının ikamet ettiği Aksaray ilindeki banka çalışanları oluşturmuştur. Yapılan incelemelerde Türkiye Bankalar Birliği'nin verileri referans alınmış ve 2015 yılı verilerine göre Aksaray ilinde faaliyet gösteren bankalarda 398 çalışan bulunduğu belirlenmiştir (Türkiye Bankalar Birliği, 2015). Anakütleden \%95 güven düzeyinde \%5'lik bir hata öngörülmüş ve araştırma için seçilecek örneklem büyüklüğünün 196 olması gerektiği gözlenmiştir (http://www.surveysystem.com/sscalc.htm). Ancak anketlerin geri dönüş oranında sorunlar yaşanabileceği ve veri kayıpları olabileceği düşünülerek 260 anket bizzat araştırmacı tarafından çalışanlara dağıtılmıştır. Örneklemde yer alacak çalışanların belirlenmesinde ise basit tesadüfi örnekleme yöntemi kullanılmıştır. Dağıtılan 260 anketin 240 tanesi geri dönmüş; bunlardan 22 tanesi ise veri kayıpları yaşanması nedeniyle değerlendirme dışı bırakılmıştır. Değerlendirmeye alınan 218 anketten erkek çalışanların kadın çalışanlardan fazla olduğu $(\% 62,4)$ ve katılımcıların çoğunun evli $(\% 60,1)$ çalışanlardan oluştuğu görülmüştür. Yaşla ilgili bulgulardan; 26-35 yaş aralığındaki $(\% 73,9)$ çalışanların oranının en yüksek, 45 yaş üstündeki çalışanların $(\% 3,2)$ oranının ise en düşük olduğu belirlenmiştir. Eğitim bulguları çalışanların büyük kısmının lisans mezunu $(\% 73,9)$ olduğunu göstermiştir. Ayrıca katılımcı çalışanların $\% 22$ 'sinin yönetici pozisyonunda bulunduğu; 1-4 yıl $(\% 49,5)$ arasında çalışan bireylerin sayıca fazla olduğu görülmüştür.

\subsection{Araştırmada Kullanılan Ölçekler}

Araştırmada nicel veriler anket tekniğiyle toplanmıştır. Araştırmada örgütsel destek algısını ölçmek için Eisenberger ve arkadaşları (1986) tarafından geliştirilen ve Armstrong-Stassen ve Ursel (2009) tarafından kullanılan 10 soruluk ölçekten yararlanılmıştır. Ölçek güvenirliliği ve geçerliliği Turunç ve Çelik (2010) tarafından da yapılmış ve ölçeğin güvenilir ve geçerli olduğu belirlenmiştir. Ölçek tek boyutlu olup 5'li Likert tipindedir (1-Kesinlikle Katılmıyorum, 5Kesinlikle Katılıyorum).

Örgütsel sinizm düzeyini ölçmek için kullanılan 13 ifadeden oluşan ölçek Brandes ve arkadaşları (1999) tarafından geliştirilmiş olup; Karacaoğlu ve İnce (2012) tarafından da Türkçe 
halinin güvenilirlik ve geçerliliği incelenmiştir. Sinizm bilişsel, duyuşsal ve davranışsal sinizm olmak üzere 3 boyutta ele alınmış olup ölçek 5'li Likert tipindedir (1-Kesinlikle Katılmıyorum, 5-Kesinlikle Katılıyorum).

Çalışanların özdeşleşme düzeyini belirlemede Mael ve Ashforth'un (1992) geliştirdiği 6 soruluk ölçek kullanılmıştır. Ölçek güvenilirliği ulusal yazında Başar ve Basım (2015) tarafından da test edilmiştir. Ölçek tek boyuttan oluşmakta olup 5'li Likert tipindedir (1-Kesinlikle Katılmıyorum, 5-Kesinlikle Katılıyorum).

Politik davranış algısı için Hochwarter ve arkadaşlarının (2003) geliştirdiği, Akdoğan ve Demirtaş'ın (2014) Türkçe'ye uyarladığı 6 sorudan oluşan ölçek kullanılmıştır. Tek boyut içeren ölçek 5'li Likert tipindedir (1-Kesinlikle Katılmıyorum, 5-Kesinlikle Katılıyorum).

Çalışanların işe bağlanma düzeyini ölçmek için Schaufeli ve arkadaşlarının (2002) geliştirdiği Utrecth İşe Bağlanma Ölçeği'nin (UWES) Schaufeli vd. (2006) tarafından kısaltılmış olan 9 maddelik versiyonu kullanılmıştır. Ölçeğin güvenilir olduğu Eyiusta'nın (2015) araştırmasıyla da desteklenmiştir. Ölçek canlılık, adanma ve yoğunlaşma olmak üzere 3 boyuttan oluşmaktadır. Ifadeler 5'li Likert tipi (1- Neredeyse hiç (yılda birkaç kere ya da daha az), 5- Çok sık(haftada birkaç kere)) derecelendirme ile ölçülmüştür.

\subsection{Araştırmada Kullanılan İstatistiki Yöntemler}

Araştırmada elde edilen veriler SPSS ve AMOS paket programları yardımıyla analiz edilmiş ve temelde açıklayıcı faktör analizi, doğrulayıcı faktör analizi, yol analizi ve yapısal eşitlik modellemesi olmak üzere dört yöntem kullanılmıştır. Bu yöntemler kullanılmadan önce elde edilen verilerin normal dağılıma uygunluğu test edilmiştir. Bu doğrultuda öncelikle Kolmogorov-Smirnov ve Shapiro-Wilk testleri yapılmıştır. Test sonuçlarının istatistiksel olarak anlamlı çıkması nedeniyle araştırmadaki verilerin normal dağılama uymadığı görülmüştür.

Araştırmada kullanılan ölçeklerin güvenilirliğini tespit etmek amacıyla ölçeğin iç tutarlılığını gösteren Cronbach Alpha Güvenilirlik Ölçütü’nden yararlanılmıştır. Cronbach alpha katsayısının 0,70 veya daha yüksek olması dikkate alınmıştır. Analizlerde ölçek maddelerine ilişkin toplam puan korelasyonu 0,30'dan küçük olan maddeler çıkarılmıştır. Yapılan analizlerde örgütsel destek algısı ölçeğinden bir (1) maddenin toplam puan korelasyonu 0,30'dan düşük olduğu için analizden çıkarılmıştır. Güvenilirlik analizlerinde algılanan örgütsel destek $(0,939)$, örgütsel sinizm $(0,948)$, örgütsel özdeşleşme $(0,918)$, politik davranış algısı $(0,891)$ ve işe bağlanma $(0,966)$ ölçeklerinin güvenilir oldukları belirlenmiştir.

\section{4. Ölçeklere İlişkin Faktör Analizleri}

Araştırmada ölçeklerin yapı geçerliliği için her bir ölçeğe sırasıyla açıklayıcı (açımlayıcı) faktör analizi ve doğrulayıcı faktör analizi yapılmıştır. Varimaks açıklayıcı faktör analizinde faktör yüklerinin alt değeri 0,40 olarak alınmış, bu değerin altındaki maddeler analizden çıkarılmıştır. Öte yandan ölçeklerde KMO (Kiaser-Meyer-Olkin Measure of Sampling Adequacy) örneklem yeterlilik ölçütünün 0,60'dan yüksek olması ve küresellik derecesinin anlamlılığının ise (Barlett's Test of Spherecity) <,05 olması dikkate alınmıştır. Açıklayıcı faktör analiziyle elde edilen faktör yapısının uyumluluğu doğrulayıcı faktör analiziyle saptanmış ve maddelerin standardize edilmiş regresyon yüklerinin 0,50'den düşük olmaması referans alınmıştır.

Örgütsel destek algısı ölçeğindeki 9 maddeye uygulanan açıklayıcı faktör analizinde KMO değeri $(0,923)$ ve küresellik testi oranı $(0,000)$ gerekli ölçütleri sağlamıştır. Analizde madde faktör yükleri 0,686-0,898 arasında değerler almış ve tek bir faktör altında birleşerek toplam varyansın \%68,055'ini açıklamıştır. Açıklayıcı faktör analizi ile elde edilen faktör yapısı doğrula- 
yıcı faktör analiziyle test edilmiştir. Bazı model uyum indeksi değerlerinin gerekli ölçütleri sağlamaması nedeniyle maddeler arasında modifikasyonlar yapılmış, modifikasyon sonrası uyum indeksi bulguları Tablo 1'de verilmiştir.

Çalışanların örgüte karşı sinizm düzeyini ölçmek için kullanılan 13 maddelik ölçeğe uygulanan açıklayıcı faktör analizinde iki (2) maddenin madde faktör yükü 0,40 'ın altında olması nedeniyle analizden çıkarılmıştır. Analizde KMO değeri $(0,960)$ ve küresellik testi oranı $(0,000)$ referans değerlerini sağlamış ve madde faktör yükleri 0,819-0,904 arasında değerler almıştır. Ölçek maddeleri tek bir faktör altında birleşerek toplam varyansın \%74,598'ini açıklamıştır. Ölçeğin faktör yapısı açıklayıcı faktör analizi ile belirlendikten sonra doğrulayıcı faktör analiziyle test edilmiştir. Bazı maddeler arasında modifikasyonlar yapılarak model uyum indeksi değerleri iyileştirilmiştir. Modifikasyon sonrası uyum indeksi bulguları Tablo 1'de sunulmuştur.

Örgütsel özdeşleşme düzeyini ölçmek için kullanılan 6 maddelik ölçeğe açıklayıcı faktör analizi uygulanmıştır. Analizde KMO değeri $(0,898)$ ve küresellik testi oranı $(0,000)$ gerekli ölçütleri sağlamıştır. Madde faktör yükleri 0,776-0,874 arasında değerler almış ve maddeler tek bir faktör altında birleşerek toplam varyansın \%71,033'ünü açıklamıştır. Açıklayıcı faktör analizi ile elde edilen faktör yapısı doğrulayıcı faktör analiziyle test edilmiştir. Öte yandan ölçek maddeleri arasında modifikasyonlar yapılarak uyum indeksi değerleri iyileştirilmiştir. Modifikasyon sonrası elde edilen uyum indeksi bulguları Tablo 1'de verilmiştir.

İşe bağlanma ölçeğindeki 9 maddeye uygulanan açıklayıcı faktör analizinde KMO değeri $(0,955)$ ve küresellik testi oranı $(0,000)$ gerekli ölçütleri sağlamıştır. Analizde madde faktör yükleri 0,873-0,908 arasında değerler almıştır. Ölçek maddelerinin tek bir faktör altında birleştiği ve toplam varyansın \%78,529'unu açıkladığı görülmüştür. Açıklayıcı faktör analizinden sonra ölçeğin faktör yapısı doğrulayıcı faktör analiziyle test edilmiştir. Öte yandan bazı ölçek maddeleri arasında modifikasyonlar yapılmış ve modifikasyon sonrası uyum indeksi bulguları Tablo 1'de sunulmuştur.

Son olarak politik davranış algısı ölçeğindeki 6 maddeye açıklayıcı faktör analizi uygulanmış; maddelerin tek bir faktöre yüklendiği ve madde faktör yüklerinin 0,723-0,870 arasında değerler aldığı görülmüştür. Ölçek faktör yapısı toplam varyansın \%64,798'ini açıklamıştır. Analiz bulguları KMO değerinin $(, 878)$ ve küresellik düzeyinin $(, 000)$ referans ölçütleri sağladığını göstermiştir. Açıklayıcı faktör analizinden sonra doğrulayıcı faktör analizi yapılmıştır. Öte yandan ölçek maddeleri arasında modifikasyonlar yapılarak uyum indeksi değerleri iyileştirilmiştir. Modifikasyon sonrası elde edilen uyum indeksi bulguları Tablo 1'de sunulmuştur.

Tablo 1: Uyum Indeksi Sonuçları

\begin{tabular}{llllllll}
\hline Indeksler & $\begin{array}{l}\text { Referans } \\
\text { Değeri }\end{array}$ & $\begin{array}{l}\text { Örgütsel } \\
\text { Destek }\end{array}$ & $\begin{array}{l}\text { Örgütsel } \\
\text { Sinizm }\end{array}$ & $\begin{array}{l}\text { Örgütsel } \\
\text { Özdeşleşme }\end{array}$ & $\begin{array}{l}\text { Işe } \\
\text { ma }\end{array}$ & $\begin{array}{l}\text { Bağlan- } \\
\text { Politik } \\
\text { Davranış } \\
\text { Algısı }\end{array}$ & $\begin{array}{l}\text { Araştırma } \\
\text { Modeli }\end{array}$ \\
\hline CMIN/DF & $0<\chi 2 / s d \leq 5$ & 1,629 & 2,655 & 2,019 & 2,336 & 1,630 & 1,461 \\
CFI & $\geq, 90$ &, 991 &, 973 &, 992 &, 984 &, 993 &, 961 \\
RMR & $\leq, 1$ &, 031 &, 035 &, 023 &, 028 &, 024 &, 066 \\
IFI & $\geq, 90$ &, 991 &, 973 &, 992 &, 984 &, 993 &, 961 \\
TLI & $\geq, 90$ &, 986 &, 963 &, 983 &, 977 &, 987 &, 958 \\
RMSEA & $<, 05-, 08 \leq$ &, 054 &, 077 &, 069 &, 078 &, 054 &, 046 \\
\hline
\end{tabular}




\subsection{Hipotezlerin Testi}

Araştırmada oluşturulan hipotezler test edilmeden önce örgütsel destek, örgütsel sinizm, örgütsel özdeşleşme, işe bağlanma ve politik davranış algısı değişkenleri arasındaki ilişkilerin yönünü ve büyüklüğünü ortaya koymak için korelasyon analizi yapılmıştır. Korelasyon analizinde elde edilen verilerin normal dağılım sergilemediği göz önüne alınarak Spearman Korelasyon Analizi tercih edilmiştir. Bulgular Tablo 2'de gösterilmiştir.

Tablo 2: Değişkenler Arasındaki Iliş̧ki

\begin{tabular}{|c|c|c|c|c|c|c|c|}
\hline Faktörler & & SS & 1 & 2 & 3 & 4 & 5 \\
\hline 1-Örgütsel Destek & 3,180 & ,998 & 1 & & & & \\
\hline 2-Örgütsel Sinizm & 2,737 & ,997 &,$- 769^{* *}$ & 1 & & & \\
\hline 3-Örgütsel Özdeşleşme & 3,554 & ,946 &, $791^{* *}$ &,$- 759^{* *}$ & 1 & & \\
\hline 4-i̇şe Bağlanma & 3,222 & 1,094 &, $794^{* *}$ &,$- 760^{* *}$ &, $771^{* *}$ & 1 & \\
\hline 5-Politik Davranış Algısı & 2,967 & ,868 &,$- 442^{* *}$ &, $558^{* *}$ &,$- 463^{* *}$ &,$- 419^{* *}$ & 1 \\
\hline
\end{tabular}

$* \mathrm{p}<0,05 \quad * * \mathrm{p}<0,01$

Tablo 2'deki bulgularda çalışanların örgütsel destek ölçeğinde genel anlamda "kararsızım" (ort. $=3,180$ ) seçeneğine yöneldiği; sinizm düzeyinin nispeten düşük (ort.= 2,737 ) olduğu, politik davranış algısının ise sinizme nazaran biraz daha yüksek (ort. $=2,967$ ) olduğu görülmektedir. Tablodan çalışanların özdeşleşme düzeyinin diğer değişkenlerden biraz daha yüksek (ort. $=3,554$ ) olduğu; işlerine bağlanma düzeyine bakıldığında da orta düzeyde (ort. $=3,222$ ) işe bağlanma sergiledikleri söylenebilir.

Tablo 2'deki değişkenler arası ilişkiler incelendiğinde; çalışanların örgütsel destek algısı ile işe bağlanma düzeyleri arasında güçlü ve doğru yönde $(r=, 794)$ bir ilişki mevcutken; çalışanların destek algısı ile politik davranış algısı arasında orta düzeyde ters yönde $(r=-, 442)$ bir ilişki vardır. Örgütsel destek ile aracı değişkenler olan örgütsel özdeşleşme arasında güçlü ve olumlu yönde $(r=, 791)$ bir ilişki bulunurken; örgütsel sinizm arasında güçlü ve olumsuz yönde ( $r=-$ ,769) bir ilişki mevcuttur.

Örgütsel özdeşleşme ile işe bağlanma ve politik davranış algısı arasındaki ilişkiler incelendiğinde; örgütsel özdeşleşme ile işe bağlanma arasındaki ilişki doğru yönlüyken $(r=, 771)$, örgütsel özdeşleşme ile politik davranış algısı arasındaki ilişki ters yönlüdür ( $r=-, 463)$.

Örgütsel sinizm ile örgütsel özdeşleşme, işe bağlanma ve politik davranış algısı arasındaki ilişkiye bakıldığında; örgütsel sinizm ile örgütsel özdeşleşme $(r=-, 759)$ ve işe bağlanma ( $r=-$ ,760) arasındaki ilişki olumsuz yöndeyken; örgütsel sinizm ile politik davranış algısı $(r=, 558)$ arasındaki ilişki olumlu yöndedir.

Araştırmada değişkenler arası ilişkiler tespit edildikten sonra hipotez testleri yapılmıştır. Hipotezlerin testinde yapısal eşitlik modellemesi ve yol analizleri kullanılmıştır. Bu analizler yapılmadan önce yapısal eşitlik modellemesinin ön koşulu olan değişkenlere ilişkin çoklu doğrusal bağlantılılık sorunu incelenmiştir. Bu sorunun belirlenmesinde bağımsız değişkenlerin varyans büyütme çapı (Variance Inflation Factor-VIF) ve tolerans indeksleri (değişkenlerce açıklanamayan varyans oranı) incelenmiştir. Analizde değişkenlerin VIF değerlerinin 10'un altında, tolerans indekslerinin ise 0,10 'un üzerinde olduğu görülmüş; dolayısıyla da çoklu doğrusalık bağlantı sorununun olmadığı, bu nedenle de yapısal eşitlik modellemesinin yapılabileceği anlaşılmıştır. Ayrıca analizlerde normal dağılım varsayımı sağlanmadığı için bootstrap 
yöntemi kullanılmıştır (Bayram, 2013). Hipotezlerin testi temel araştırma modeli üzerinden gerçekleştirilmiştir ve test edilen modelin kestirim sonuçları Şekil 2'de verilmiştir.

Şekil 2: Standardize Edilmiş Kestirim Sonuçlarının Model Üzerinde Gösterilmesi

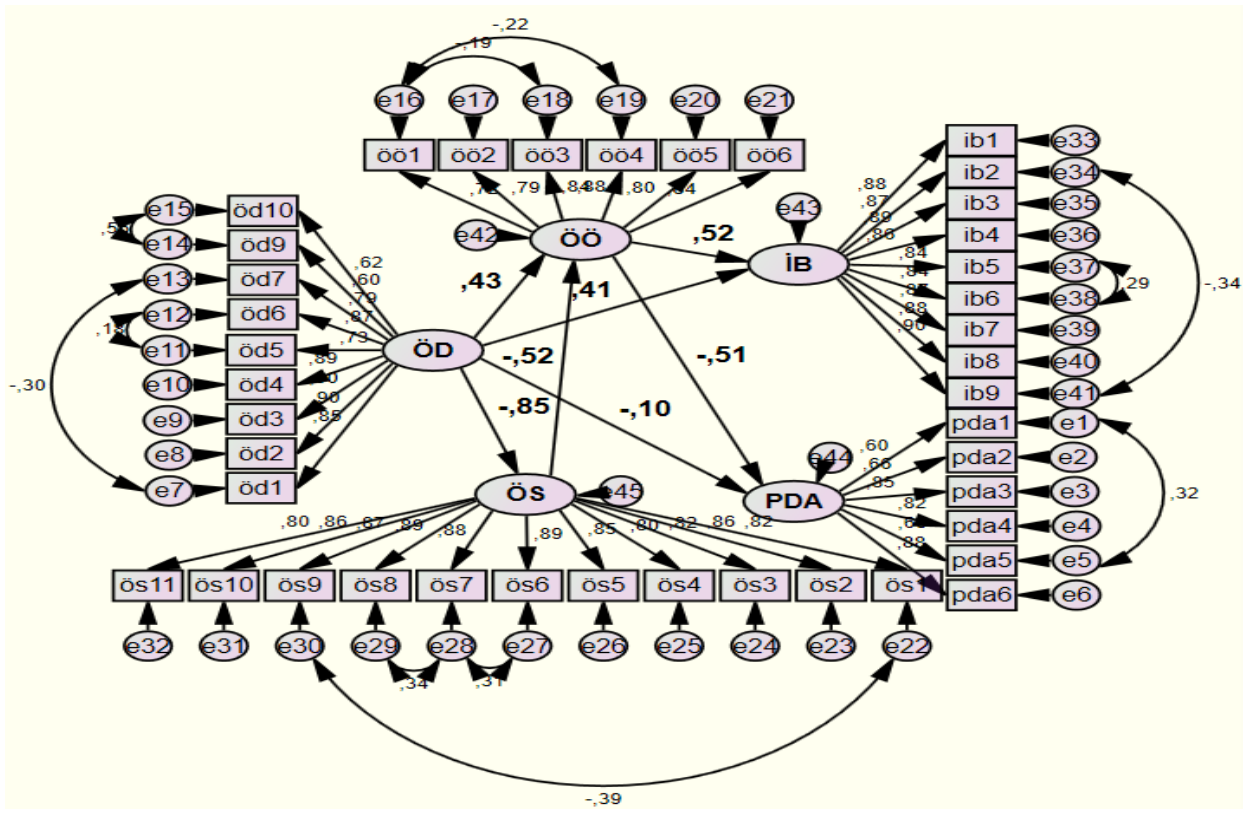

Modelde ÖD: Örgütsel destek, Ös: Örgütsel sinizm, ÖÖ: Örgütsel Özdeşleşme, ỉ: İşe Bağlanma ve PDA: Politik Davranış Algısı.

Araştırma hipotezlerinin testine ilişkin yapılan analizde modelin kestirim değerleri Tablo 3'de gösterilmektedir.

Tablo 3: Modelin Kestirim Sonuçları

\begin{tabular}{llllllll}
\hline Hipotez & $\begin{array}{l}\text { Yordanan } \\
\text { Değişken }\end{array}$ & & $\begin{array}{l}\text { Yordayan } \\
\text { Değişken }\end{array}$ & $\begin{array}{l}\text { Standardize } \\
\text { Y. }\end{array}$ & $\begin{array}{l}\text { R.t } \\
\text { Düzey }\end{array}$ & Üst Düzey & p \\
\hline $\mathrm{H}_{4}$ & ÖS & $<---$ & ÖD &,- 850 &,- 897 &,- 783 &, $\mathbf{0 0 2}$ \\
$\mathrm{H}_{3}$ & ÖÖ & $<---$ & ÖD &, 426 &, 257 &, 587 &, 002 \\
$\mathrm{H}_{7}$ & ÖÖ & $<---$ & ÖS &,- 521 &,- 677 &,- 361 &, 002 \\
$\mathrm{H}_{1}$ & IB & $<---$ & ÖD &, 406 &, 170 &, 610 &, 004 \\
$\mathrm{H}_{2}$ & PDA & $<---$ & ÖD &,- 102 &,- 484 &, 306 &, 490 \\
$\mathrm{H}_{5}$ & IB & $<---$ & ÖÖ &, 519 &, 310 &, 734 &, 003 \\
$\mathrm{H}_{6}$ & PDA & $<---$ & ÖÖ &,- 509 &,- 933 &,- 165 &, 005 \\
\hline
\end{tabular}

Hipotez testine ilişkin Şekil 2 ve Tablo 3'teki bulgular incelendiğinde; örgütsel desteğin işe bağlanmayı \%99 önem düzeyinde olumlu ve anlamlı olarak doğrudan etkilediği (,406 ve $p=, 004)$, politik davranış algısını ise doğrudan etkilemediği $(-, 102$ ve $p=, 490)$ görülmektedir. Dolayısıyla $\mathrm{H} 1$ desteklenmiş, $\mathrm{H} 2$ ise desteklenmemiştir.

Şekil 2 ve Tablo 3'teki bulgulara göre temel modelde örgütsel destek algısı örgütsel özdeşleşmeyi doğrudan olumlu ve anlamlı düzeyde $(, 426$ ve $p=, 002)$ ve örgütsel destek sinizmi olumsuz ve anlamlı düzeyde $(-, 850$ ve $p=, 002)$ etkilemekte; dolayısıyla $\mathrm{H} 3$ ve $\mathrm{H} 4$ desteklenmektedir. Bulgulardan örgütsel özdeşleşmenin işe bağlanmayı olumlu ve anlamlı olarak (,519 
ve $p=, 003)$, örgütsel özdeşleşmenin politik davranış algısını olumsuz ve anlamlı olarak (-,509 ve $\mathrm{p}=, 005) \% 99$ önem düzeyinde etkilediği, dolayısıyla da H5 ve H6'nın desteklendiği belirlenmiştir. Örgütsel sinizmin örgütsel özdeşleşmeye etkisi incelendiğinde etkinin \%99 önem düzeyinde olumsuz yönde ve anlamlı düzeyde $(-, 821$ ve $p=, 002)$ olduğu gözlenmiştir. Dolayısıyla H7 desteklenmiştir.

Araştırmada aracı hipotezlerin testi için Baron ve Kenny'nin (1986) aracılık role ilişkin kriterleri dikkate alınmıştır. Bu kriterlere göre (1) bağımsız değişkenin (yordayan) bağımlı değişken (yordanan) üzerindeki etkisinin anlamlı olması, (2) bağımsız değişkenin aracı değişkeni anlamlı etkilemesi ve (3) aracı değişkenin bağımlı değişkeni anlamlı etkilemesi gerekmektedir. Analizde aracı değişkenin modele eklenmesiyle bağımsız değişkenin bağımlı değişken üzerindeki etkisi anlamlı bir şekilde azalıyor ise kısmi aracılık; bağımsız değişkenin bağımlı değişken üzerindeki etkisi tümüyle ortadan kalkıyor -yani anlamlı etkilemiyor- ise tam aracılık mevcuttur. Araştırmada bu kriterler doğrultusunda öncelikle aracısız doğrudan etkiler ile aracılı doğrudan etkilere bakılmıştır. Sonrasında ise aracı değişkenlerin dolaylı etkilerinin anlamlılık düzeyleri incelenmiştir. Aracı değişkenlerin modelden çıkarılması ve modele eklenmesiyle elde edilen bulgular Tablo 4'de gösterilmiştir.

Tablo 4: Aracı Değişkenlerin Anlamlılık Düzeyi

\begin{tabular}{lllll}
\hline Hipotez & ilişki & Aracısız Doğrudan Etki & Aracılı Doğrudan Etki & Dolaylı Etki \\
\hline H8 & ÖD-ÖÖ-iB &, $857(p=, 004)$ &, $406(p=, 004)$ &, $003 \mathrm{Kısmi} \mathrm{aracı}$ \\
H9 & ÖD-ÖÖ-PDA &,$- 542(p=, 003)$ &,$- 102(p=, 490)$ &, 005 Tam aracı \\
H10 & ÖD-ÖS-ÖÖ &, $864(p=, 002)$ &, $426(p=, 002)$ &, $002 \mathrm{Kısmi} \mathrm{aracı}$ \\
\hline
\end{tabular}

Tablo 4'te görüldüğü gibi örgütsel özdeşleşmenin örgütsel destek ile işe bağlanma arasındaki ilişkide aracı rolünü belirlemek için öncelikle özdeşleşme aracı değişkeni modelden çıkarılmış, bu durumda örgütsel destek çalışanların işe bağlanma düzeyini \%99 önem düzeyinde güçlü bir şekilde etkilemiştir (,857 ve $p=, 004)$. Akabinde aracı değişken olan örgütsel özdeşleşme modele eklenmiş ve sonuçlar örgütsel desteğin işe bağlanmayı \%99 önem düzeyinde anlamlı bir şekilde etkilediğini, fakat etkinin azaldığını göstermiştir (,406 ve $p=, 004)$. Bununla birlikte aracı değişken olan örgütsel özdeşleşmenin anlamlı bir etkisinin olduğu gözlenmiştir $(, 003)$. Ayrıca modelin son halinde örgütsel destek özdeşleşmeyi anlamlı $(p=, 002)$ bir şekilde etkilemiştir (Tablo 3). Bu sonuçlar özdeşleşmenin örgütsel desteğin işe bağlanmaya etkisinde kısmi aracı rol üstlendiğinin ve $\mathrm{H}^{\prime}$ 'in desteklendiğinin göstergesidir. Diğer bir ifadeyle örgütsel destek işe bağlanmayı doğrudan etkileyebildiği gibi aracı değişken olan örgütsel özdeşleşme yoluyla da etkileyebilmektedir.

Tablo 4'te görüldüğü gibi örgütsel desteğin çalışanların politik davranış algısına etkisinde örgütsel özdeşleşmenin aracı rol üstlenip üstlenmediğini belirlemek için öncelikle özdeşleşme aracı değişkeni modelden çıkarılmış ve sonuçlar örgütsel desteğin çalışanların politik davranış algısını \%99 önem düzeyinde etkilediğini göstermiştir $(-, 542$ ve $p=, 003)$. Daha sonra aracı değişken olan örgütsel özdeşleşme modele dâhil edilmiş ve bu durumda örgütsel desteğin politik davranış algısını anlamlı bir düzeyde etkilemediği görülmüştür (-102 ve $p=, 490)$. Bunun yanında son durumda aracı değişken olan örgütsel özdeşleşmenin anlamlı bir etkisinin $(, 005)$ bulunduğu gözlenmiştir. Öte yandan mevcut durumda örgütsel desteğin de özdeşleşme üzerinde anlamlı bir etkisi bulunmuştur $(p=, 002)$. Aracı değişken olan özdeşleşmenin modele dâhil edilmesiyle örgütsel desteğin politik davranış algısı üzerindeki etkisinin ortadan kalktığı bulgu- 
su göz önüne alındığında; özdeşleşmenin örgütsel desteğin politik davranış algısına etkisinde tam aracı rol üstlendiği, dolayısıyla H9'un desteklendiği söylenebilir.

Tablo 4'te örgütsel sinizm bağlamında da örgütsel desteğin özdeşleşmeye etkisi görülmektedir. Bulgulardan sinizm aracı değişkeninin modelden çıkarıldığı durumda örgütsel desteğin özdeşleşmeye etkisinin \%99 önem düzeyinde anlamlı olduğu görülmektedir (,864 ve $p=, 002$ ). Sonrasında örgütsel sinizm aracı değişkeni modele eklendiğinde sonuçlar örgütsel desteğin örgütsel özdeşleşmeye etkisinin \%99 önem düzeyinde anlamlı olduğunu, fakat etki düzeyinin azaldığını göstermiştir (,426 ve $p=, 002)$. Bulgular modeldeki aracı değişken olan örgütsel özdeşleşmenin anlamlı bir etkisinin $(, 002)$ bulunduğunu da göstermiştir. Öte yandan modelin son durumunda örgütsel destek örgütsel sinizmi de anlamlı düzeyde etkilemiştir $(, 002)$. Sonuç itibariyle aracı değişkenin modele eklenmesiyle birlikte örgütsel desteğin örgütsel özdeşleşmeye etkisi ortadan kalkmamış, bu nedenle de örgütsel sinizm söz konusu etkide kısmi aracı rol üstlenmiştir. Elde edilen tüm bulgulardan H10'un desteklendiği tespit edilmiştir.

\section{Değerlendirme ve Sonuç}

Bu çalışmada algılanan örgütsel desteğin, işe bağlanma ve politik davranış algısı üzerindeki etkisi ve bu etkide özdeşleşmenin rolü belirlenmiştir. Ayrıca algılanan örgütsel desteğin özdeşleşme üzerindeki etkisi ve bu etkide sinizmin rolü de incelenmiştir. Bu doğrultuda 218 banka çalışanından veriler elde edilmiş ve bulgular aşağıda özetlenmiştir:

Araştırmadaki temel modelde örgütsel desteğin işe bağlanmayı olumlu yönde ve anlamlı düzeyde etkilediği görülmüştür. Elde edilen bu bulgu daha önce yapılan çalışmalarda (örneğin; Ince, 2016; Saks 2006; Rich vd., 2010; Kim, 2012; Gupta vd., 2016; Jin ve McDonald, 2016) elde edilen bulgularla örtüşmektedir. Örgütte çalışanın sarf ettiği çabanın dikkate alınması, yaptığı katkının önemsenmesi ve ihtiyaçlarının karşılanması çalışanın örgütünden destek algılamasını sağlamaktadır. Örgütten destek aldığını düşünen çalışan da işine tümüyle yoğunlaşmakta ve iş rollerinin gereğini istekli bir şekilde yerine getirmektedir.

Temel modelde çalışana verilen desteğin doğrudan onun politik davranış algısını etkilemediği; etkinin dolaylı olarak gerçekleştiği bulunmuştur. Dolayısıyla örgütsel desteğin özdeşleşme düzeyini artırarak politik davranış algısını azalttığı anlaşılmıştır. Örgüt ve yönetici tarafından çalışana beklediği değerin verilmesi ve ihtiyaçlarının karşılanmasıyla birlikte örgüt ile bütünleşme ve aitlik duygusu hissetme söz konusu olmuştur. Örgütüne ait olduğunu düşünen çalışan da örgütte daha az politik davranış sergilendiğini düşünmüştür. Kendisini örgütün bir parçası olarak gören çalışan örgütte kişisel çıkarlar yerine ortak çıkarların ön planda olduğunu düşünmeye başlamıştır.

Örgütsel destek algısının örgütle özdeşleşme üzerindeki etkisi incelendiğinde; temel modelde desteğin özdeşleşmeyi olumlu yönde ve anlamlı derecede etkilediği görülmüştür. Sonuç itibariyle çalışanın katkılarına değer verildiğini, performansının dikkate alındı̆̆ını ve yeterli düzeyde ödüllendirildiğini algılaması onun örgüt ile birliktelik hissetmesini ve örgütün başarı ve başarısızlıklarını kişisel olarak üstlenmesini sağlamıştır. Elde edilen bu sonuç geçmiş çalışmaların (Turunç ve Çelik, 2010; Ertürk, 2010; Cheung ve Law, 2008; Sluss vd. 2008; He vd. 2014; Zagenczyk vd. 2011) sonuçlarıyla paraleldir. Bu bulgu doğrultusunda, çalışanın örgütü benimsemesini ve onun başarı ve başarısızlı̆̆ını üstlenmesini isteyen yöneticilere, çalışana değer verdiklerini hissettirmesi ve onun başarılarını ödüllendirerek performansını dikkate alması önerilebilir. 
Temel model bulgularına göre örgütsel desteğin sinizm üzerindeki etkisi anlamlı ve olumsuz yönde belirlenmiştir. Dolayısıyla çalışanların örgütten gördükleri destek arttıkça örgüte karşı sergiledikleri sinik davranışlar azalmaktadır. Bu bulgu Byrne ve Hochwarter (2008), Chiaburu ve arkadaşları (2013), Kasalak ve Aksu (2014), Tokgöz (2011) ve Treadway ve arkadaşlarının (2004) araştırma bulgularıyla benzerlik göstermektedir. Sonuç olarak, örgütün çalışanın iyiliğini ve mutluluğunu düşünmesi ve ihtiyaçlarını karşılaması onun destek algısını güçlendirmiştir. Destek algısı güçlenen çalışan da örgüte karşı olumsuz duygularını ve eleştirel davranışlarını azaltmıştır. Buna göre çalışanın üyesi olduğu örgüte karşı olumsuz duygularını, eleştirel davranışlarını, öfke ve nefret duygularını azaltıp, çalışana örgütün dürüst, adil ve samimi olduğunu göstermek isteyen yöneticilerin, çalışanı önemsemesi, onun gayret ve çabalarını dikkate alması ve maddi ve sosyo-psikolojik ihtiyaçlarını karşılaması gerekmektedir.

Örgütsel özdeşleşmenin işe bağlanma üzerindeki etkisine bakıldığında da, olumlu yönlü ve anlamlı bir etkinin olduğu bulunmuştur. Bu bulgu Gözükara ve Şimşek'in (2016), KaranikaMurray ve arkadaşlarının (2015) ve Ötken ve Erben'in (2010) araştırma bulgularıyla tutarlıdır. Çalışanın örgütüyle bütünleşmesi ve kendini onun bir parçası olarak görmesiyle birlikte işine tamamen yöneldiği, iş yükümlülüklerini yerine getirmeye istek duyduğu ve enerjik olduğu bulunmuştur.

Temel modelde örgütsel özdeşleşmenin politik davranış algısına etkisi de anlamlı çıkmış olup bu etkinin olumsuz yönde olduğu görülmüştür. Bu bulgu özdeşleşme ile politik davranış algısı arasında ters yönlü ilişki olduğunu öne süren Erkutlu ve Chafra'nın (2016) araştırmasıyla tutarlıdır. Örgütün amaç ve değerlerini kişisel olarak benimseyen ve onunla bütünleşen çalışanlar, ilişkilerin kişisel çıkarlardan ziyade ortak çıkarlar doğrultusunda kurulduğunu düşünebilir. Nitekim elde edilen bulgu bu beklentiyi desteklemiştir.

Örgütsel sinizmin özdeşleşmeye etkisine bakıldığında da çalışanın örgüte ve iş arkadaşlarına güvensizlik duyma, onları küçümseme ve örgütün dürüstlükten yoksun olduğunu düşünme gibi duygu ve düşünceler taşımasıyla birlikte, çalışanın örgüt ile birlikteliğinin ve ait olma duygusunun azaldığı görülmüştür. Bu bulgu Bedeian'ın (2007) araştırma bulgusuyla paraleldir. Dolayısıyla çalışanı örgüt ile bütünleştirip örgüte aidiyet duygusu hissettirme amacı güden banka yöneticilerinin öncelikle çalışanın örgüte ve iş arkadaşlarına güven duymasını sağlaması gerekmektedir. Zira çalışanın hem örgüte hem de iş arkadaşlarına güven duyması, örgütü küçümseyici davranışından uzaklaşmasını sağlayacaktır.

Bu araştırmada doğrudan etkilere ilişkin söz konusu bulguların yanında, aracılık ilişkisine yönelik bulgular da incelenmiştir. Yapılan analizlerde örgütsel desteğin hem doğrudan hem de örgütsel özdeşleşme üzerinden işe bağlanmayı etkilediği, yani örgütsel desteğin işe bağlanmaya etkisinde özdeşleşmenin kısmi aracı rol üstlendiği görülmüştür. Aracılığın kısmi olması, örgütsel desteğin işe bağlanmaya etkisinde özdeşleşmenin yanında başka değişkenlerin de aracı olduğunu göstermektedir. Bulgulara göre, örgütün çalışanın iyiliğini ve mutluluğunu önemsemesi ve onun katkılarını dikkate alarak performansını ödüllendirmesi, çalışanın işiyle bütünleşmesine ve tümüyle işine odaklanmasına yol açmıştır. Bunun yanında, örgütün ve yöneticinin çalışanın iyiliğini ve mutluluğunu önemsemesi ve katkılarını dikkate alarak performansını ödüllendirmesi, onun örgüte aidiyet hissetmesini ve örgütün başarı ve başarısızlığını kişisel olarak üstlenebilmesini sağlamıştır. Örgüte aidiyet hisseden çalışan da işiyle bütünleşip, tümüyle işine yoğunlaşmıştır.

Örgütsel desteğin politik davranış algısına etkisinde özdeşleşmenin aracılık rolünü belirlemek için yapılan analizlerde, örgütsel desteğin politik davranış algısına doğrudan etkisinin 
olmadığı; etkinin dolaylı olarak özdeşleşme üzerinden gerçekleştiği, yani özdeşleşmenin tam aracı rol üstlendiği belirlenmiştir. Başka bir deyişle, örgütsel destek algısı çalışanın özdeşleşme düzeyini artırarak politik davranış algısını azaltmıştır. Dolayısıyla örgütün çalışanın iyiliğini ve mutluluğunu önemsemesi ve ihtiyaçlarını karşılaması onun aidiyet hissetmesini ve örgütün başarı ve başarısızlığını kişisel olarak üstlenebilmesini sağlamıştır. Kendisini örgüte ait hisseden çalışan da örgütte kişisel çıkarları korumaya ilişkin davranışların daha az sergilendiğini düşünmüş; kişisel çıkarlardan ziyade ortak çıkarların ön planda tutulduğuna inanmıştır.

Örgütsel desteğin özdeşleşmeye etkisinde sinizmin aracılık rolüne ilişkin bulgulara göre örgütsel destek hem doğrudan hem de örgütsel sinizm üzerinden özdeşleşmeyi etkilemektedir; yani desteğin özdeşleşmeye etkisinde sinizmin kısmi aracı rol üstlendiği belirlenmiştir. Bir diğer ifadeyle; örgütün çalışanı önemsemesi, katkılarını dikkate alması ve performansını ödüllendirmesi onun örgütüyle bütünleşmesini, aidiyet hissetmesini ve kendisini örgütün bir parçası olarak görmesini sağlamıştır. Örgütün çalışanı önemsemesi ve katkılarını dikkate alması onun örgüte karşı olumsuz tutum ve davranışlarını azaltmış; nihayetinde de çalışan örgütüyle bütünleşmiş ve kendisini örgütün bir parçası olarak görmüştür.

Araştırmada elde edilen tüm bu bulgular sosyal değişim teorisi (Blau, 1964) ve karşılıklılık normu (Gouldner, 1960) bakış açılarını desteklemektedir. Bu bakış açıları doğrultusunda çalışanın işine tümüyle kendisini vermesini ve işini benimsemesini bekleyen ve örgütte kişisel çıkarları korumaya ilişkin davranışların daha az sergilendiğini düşünmesini isteyen yöneticilerin öncelikle çalışanın örgüte yaptığı katkıyı önemsemesi ve ihtiyaçlarını karşılaması gerektiğini göstermektedir. Yapılan katkının örgüt ve yönetici tarafından dikkate alınması, performansın ödüllendirilmesi ve ihtiyaçların karşılanması çalışanın örgüte yönelik olumsuz düşüncelerini azaltmış, örgütü küçümseyici davranışlardan uzaklaştırmıştır. Bu durum çalışanın örgütü kişisel olarak benimsemesini ve örgütle bütünleşmesini sağlamıştır. Örgütle bütünleşen çalışan ise hem işine tüm enerjisini verip yoğunlaşmış, hem de kendine hizmet etme davranışını daha az algılamıştır. Dolayısıyla örgütün çalışana yaptığı olumlu yatırım, çalışanın da örgüte olumlu katkılar yapması yükümlülüğünü ortaya çıkarmıştır.

İşe bağlanma ve politik davranış algısını etkileyen örgütsel faktörlerin, kültürel özellikler göz önüne alınarak da değerlendirilmesi gerekir. Örneğin, örgüt kültürünün rekabetçi, yenilikçi ve performans yönelimli olması işe bağlanmayı artırmaktadır (Barbars, 2016). Kültürün rekabetçi olması, çalışan her ne kadar destek algılamasa ve kendini örgütün bir parçası olarak görmese de onun fiziksel olarak işe bağlanmasını sağlayabilir. Benzer şekilde, çalışan örgütün kendisini önemsediğini düşünmese de, örgüt kültürünün performans yönelimli olmasıyla çalışanın işine bağlanması beklenebilir. Örgütteki politik davranış algısı için de buna benzer bir yorum yapılabilir. Çalışan örgütten destek aldığını düşünüp örgüt ile bütünleşse bile örgütte paylaşılan değerlerin politik davranışları bazı konularda desteklemesi, politik davranış algısını artırabilir. Bunun tersi bir durumda, yani çalışan örgütten destek aldığını düşünmediğinde ve kendisini örgüte ait hissetmediğinde, kültürün örgütte sergilenen politik davranışları cezalandırmasıyla çalışanın politik davranış algısı düşük olabilir. Dolayısıyla gelecekte yapılacak araştırmalarda, mevcut modele kültürel özellikleri ifade eden birtakım değişkenlerin eklenmesi ve söz konusu değişkenlerin etkilerinin incelenmesi literatüre önemli bir katkı sağlayabilir.

Araştırma ile elde edilen bulgular kontrol değişkenleri açısından değerlendirildiğinde; kadınların örgütsel destek algısının erkeklere oranla daha fazla olduğu bulunmuştur. Aynı durum örgütsel özdeşleşme düzeyinde de görülmüştür. Kadınların örgütleriyle bütünleşme ve ait olma duygusu erkeklere göre daha yüksektir. Bu bulgu İşcan'ın (2006) araştırma bulgusuyla 
çelişmektedir. Bu durumun nedeni kadınların iş hayatındaki çalışma alanının kısıtlı olması ve erkeklere göre örgütlerine daha duygusal yaklaşması olabilir.

Medeni durum ve yöneticilik görevi değişkenleri açısından çalışanların örgütsel destek, sinizm, özdeşleşme, işe bağlanma ve politik davranış algısında anlamlı bir farklılık gözlenmemiştir.

Yaş değişkeni açısından da çalışanların destek algısı ve özdeşleşme düzeylerinde farklıılılar gözlenmiştir. 25 yaş ve altındaki çalışan grubunun, diğer yaş gruplarına oranla örgütsel destek algısının daha fazla olduğu görülmüştür. Bu bulgu literatürde yapılan bazı ampirik araştırma bulgularıyla (Moideenkutty vd. 2001) tutarlıdır. Örgütsel özdeşleşme düzeyindeki farklılık 25 yaş ve altı çalışanlar ile $26-35$ yaş ve $36-45$ yaş arasındaki çalışanlardan kaynaklanmıştır. 25 yaş ve altındaki çalışanların diğer yaş gruplarına oranla özdeşleşme düzeylerinin daha yüksek olduğu belirlenmiştir. Bu bulgu Çakınberk ve arkadaşlarının (2011) araştırmalarında elde ettiği yaş grubuna göre çalışanların özdeşleşme düzeylerinin farklılaşabileceği bulgusunu desteklemektedir. Bu durumun nedeni, 25 yaş ve altındaki çalışanların iş hayatının muhtemelen başlangıcında olmaları sebebiyle örgütlerini daha fazla önemsemesi ve örgütle özdeşleşmeye daha fazla istekli olması olabilir.

Bulgular eğitim değişkeni açısından ele alındığında, çalışanların örgütsel destek, sinizm, özdeşleşme ve işe bağlanma düzeylerinde anlamlı farklılıklara rastlanmıştır. Örgütsel desteğe ilişkin farklılık lisans ve lisansüstü derecesine sahip çalışanlar arasında mevcuttur. Buna göre lisansüstü düzeyindeki çalışanların destek algısı, lisans derecesine sahip çalışanlardan daha düşüktür. Örgütsel sinizmdeki farklılık ise lisansüstü derecesine sahip çalışanlardan kaynaklanmakta olup, lisansüstü çalışanların sinizm düzeyi diğer tüm eğitim gruplarından daha yüksektir. Bu bulgu Tokgöz ve Yılmaz'ın (2008) araştırma bulgularıyla paralellik göstermektedir. Örgütsel sinizmdeki farklılığın benzeri özdeşleşme düzeyi için de geçerlidir. Diğer bir ifadeyle, lisansüstü eğitim düzeyindeki çalışanlar diğer tüm eğitim gruplarına nazaran örgüt ile daha az bütünleşmekte ve örgüte daha az ait olduğunu hissetmektedir. Çalışanların işe bağlanma düzeyindeki farklılığın kaynağına bakılırsa; fark lise ve altı ile lisansüstü ve lisans ile lisansüstü derecesine sahip çalışanlar arasında mevcuttur. Lisansüstü eğitim düzeyindeki çalışanlar hem lise ve altı, hem de lisans eğitim düzeyindeki çalışanlara göre işlerine daha az bağlıdır. Bu durumun nedeni, lisansüstü çalışanların eğitim yoluyla kendilerini daha fazla geliştirmesi ve diğer çalışanlara nazaran daha donanımlı olduklarını düşünmesi nedeniyle örgütten ve işlerinden beklentilerinin fazla olması olabilir. Öte yandan eğitim düzeyi yüksek olan bu çalışanların başka işletmelerde de iş imkânları bulabilmesi örgüte ve işlerine daha eleştirel yaklaşmalarına yol açabilir. Aynı nedenle bu çalışanlar örgütün başarı ve başarısızlığını kişisel olarak üstlenmemekte ve işlerine kendilerini tümüyle vermemektedir.

Çalışanların çalışma süresi açısından sadece örgütsel destek algısında anlamlı bir farklıık tespit edilmiştir. Farkın nedeni 1 yıldan az süredir çalışan bireylerin diğer çalışanlardan daha fazla destek algılamasıdır. Bu durumun nedeni, bu çalışanlara işe yeni başlamaları sebebiyle işlerini ve örgütü tanıtıcı oryantasyon çalışmaları yapılması, onlarla özel olarak ilgilenilmesi ve onların da bu faaliyetleri destek faaliyetleri olarak değerlendirmesi olabilir.

Bu araştırmada elde edilen bulguların bankacılık sektöründeki örgütlere ve yöneticilere yol göstereceği düşünülmektedir. Banka yöneticilerinin günümüz iş dünyasında beşeri kaynak yönetimine daha fazla odaklanması önem arz etmektedir. Yöneticilerin örgütün yaşamını sürdürmesi ve amaçlarına ulaşması için hem müşteri odaklı ve yetenekli çalışanları işe alması, hem de bu özelliklere sahip çalışanların işlerine tümüyle kendini vermesini ve yeteneklerini 
işlerinde kullanmasını sağlaması gerekir. Sektörün hizmet sektörü olması nedeniyle çalışandan müşteri odaklı olması beklenmektedir. Çalışanın müşteri odaklı olabilmesi ise işine yüksek düzeyde bağlanmasını, işine hem fiziksel hem bilişsel hem de duygusal olarak kendisini vermesini gerektirmektedir.

Çalışanın işine yüksek düzeyde bağlanması öncelikle banka yöneticilerinin çalışana destekleyici davranışlar sergilemesi, çalışanın da bu davranışları algılamasıyla sağlanabilir. Örgüt yöneticisinin çalışana beklediği değeri verilmesi, çalışanın bu durumu tüm örgüte atfetmesini sağlar. Dolayısıyla çalışan örgüte karşı olumlu düşünceler geliştirmeye başlar ve örgütü kişisel olarak benimser. Sonuç itibarıyla örgüte zarar verici davranışlar sergilemekten kaçınır. Çalışanın kendisini örgütün bir parçası olarak görmesi belirlenen misyon ve vizyonu başarma görevini kişisel olarak üstlenmesini sağlar. Bu doğrultuda çalışan işine tüm enerjisini verir ve iş yükümlülüklerini istekli bir şekilde yerine getirir, hatta bu yükümlülüklerin ötesine bile geçebilir.

\section{Araştırmanın Kısıtları ve Gelecek Araştırmalar İçin Öneriler}

$\mathrm{Bu}$ araştırmanın en önemli kısıtlarından biri, verilerin önceden hazırlanmış soru formuna bağlı olarak elde edilmesi, kesitsel veri toplanmış olması ve bulguların sadece örneklemin özellikleriyle sınırlı olmasıdır. Nitekim kesitsel araştırmada sadece bir defa veri toplanmakta ve elde edilen veriler çalışanın o anki psikolojik durumuna ve algısına bağı kalmaktadır. Öte yandan, verinin toplandığı dönemde ülkede olağanüstü halin ilan edilmesi nedeniyle anketlerin bu psikolojik durum altında cevaplanması; olağanüstü halden sonraki dönemlerde aynı örneklemden tekrardan veriler toplanarak karşılaştırmanın yapılmaması da bir kısıt olabilir.

Araştırmanın sadece bankacılık sektörünü kapsaması, maliyet ve ulaşılabilirlik nedenleriyle tek bir ili içeren veriler toplanması da araştırmadaki bir diğer kısıttır. Gelecek araştırmaların örneklem büyüklüğünü artırarak farklı bölgelerdeki veya şehirlerdeki bankalarla karşılaştırma yapması önerilebilir. Ayrıca gelecek araştırmalarda araştırma modeli farklı sektörlerden ve farklı meslek gruplarından çalışanlar üzerinde test edilebilir.

Araştırmada sinizmin sadece destek algısıyla özdeşleşme arasındaki rolü incelenmiş, işe bağlanma ve politik davranış algısıyla ilişkisi değerlendirilmemiştir. Gelecek araştırmalarda sinizm ile işe bağlanma ve politik davranış algısı arasındaki ilişkilere bakılması önerilebilir.

Araştırmada ele alınan değişkenler arasında ulusal kültürün ya da örgüt kültürünün özelliklerini ortaya koyan herhangi bir değişken bulunmamaktadır. Gelecek araştırmalarda kültürel değişkenler modele eklenerek ilişkiler incelenebilir. 


\section{Kaynaklar}

Akdoğan, Asuman; Demirtaş, Özgür (2014), “Etik Liderlik Davranışlarının Etik İklim Üzerindeki Etkisi: Örgütsel Politik Algılamaların Aracı Rolü”, AKÜ iiBF Dergisi, Vol. XVI, No. 1: 107-123.

Andersson, Lynne (1996), "Employee Cynicism: An Examination Using a Contract Violation Framework", Human Relations, Vol. 49: 1395-1418.

Andersson, Lynne M.; Bateman, Thomas S. (1997), “Cynicism in the Workplace: Some Causes and Effects”, Journal of Organizational Behavior, Vol. 18: 449-463.

Andrews, Martha C.; Kacmar, K. Michele (2001), "Discriminating among Organizational Politics, Justice and Support", Journal of Organizational Behavior, Vol. 22: 347-366.

Armstrong-Stassen, Marjorie; Ursel, Nancy D. (2009), "Perceived Organizational Support, Career Satisfaction and The Retention of Older Workers", Journal of Occupational and Organizational Psychology, Vol. 82: 201-220.

Aselage, Justin; Eisenberger, Robert (2003), “Perceived Organizational Support and Psychological Contracts: A Theoretical Integration", Journal of Organizational Behavior, Vol. 24: 491-509.

Ashforth, Blake E.; Mael, Fred (1989), "Social Identity Theory and the Organization", The Academy of Management Review, Vol. 14, No. 1: 20-39.

Bakker, Arnold B.; Schaufeli, Wilmar B.; Leiter Michael P.; Taris, Toon W. (2008), "Work Engagement: An Emerging Concept in Occupatinal Health Psychology", Work \& Stress, Vol. 22, No. 3: 187-200.

Baran, Benjamin E.; Shanock, Linda Rhoades; Miller, Lindsay R. (2012), “Advancing Organizational Support Theory into the Twenty-First Century World of Work", Journal of Business Psychology, Vol. 27: 123-147.

Barbars, Arturs (2016), "Interaction Between Organizational Culture and Work Engagement in The Information and Communication Technology Sector in Latvia", Journal of Business Management, Vol. 12: 84-100.

Baron, Reuben M.; Kenny, David A. (1986), "The Moderator-Mediator Variable Distinction in Social Psychological Research Conceptual, Strategic and Statistical Considerations”, Journal of Personality and Social Psychology, Vol. 51, No. 6: 1173-1182.

Basar, Ufuk; Filizöz, Berrin (2015), "Can Ethical Leaders Heal The Wounds? An Empirical Research", Eurasian Journal of Business and Economics, Vol. 8, No. 15: 199-218.

Başar, Ufuk; Basım, Nejat (2015), "Effects of Organizational Identification on Job Satisfaction: Moderating Role of Organizational Politics", Yönetim ve Ekonomi, Vol. 22, No. 2: 663-683.

Başar, Ufuk; Alan, Hale, Topçu, Mustafa Kemal; Aksoy, Seval (2015), “Örgütsel Politika Algısının Ardılları Üzerine Görgül Bir Araştırma”[Bildiri], 3. Örgütsel Davranış Kongresi, 6-7 Kasım 2015, (ss. 650-655), Tokat: Gaziosmanpaşa Üniversitesi.

Bayram, Nuran (2013), Yapısal Eşitlik Modellemesine Giriş: Amos Uygulamaları, Bursa: Ezgi Kitabevi.

Bedeian, Arthur G. (2007), "Even if the Tower is 'Ivory', It isn't white: Understanding the Consequences of Faculty Cynicism", Academy of Management Learning \& Education, Vol. 6, No. 1: 9-32.

Biggs, Amanda; Brough, Paula; Barbour, Jennifer P. (2014), "Relationships of İndividual and Organizational Support With Engagement: Examining Various Types of Causality in a Three-Wave Study", Work \& Stress, Vol. 28, No. 3: 236-254.

Blau, Peter M. (1964), Exchange and Power in Social Life, New York: Wiley.

Brandes, Pamela; Dharwadkar, Ravi; Dean, James W. (1999), “Does Organizational Cynicism Matter?: Employee and Supervisor Perspectives on Work Outcomes", 36th Annual Meeting of the Eastern Academy of Management, Philadelphia PA., 1-34.

Brandes, Pamela M. (1997), Organizational Cynicism: Its Nature, Antecedents and Consequences, (Doktora Tezi), Oklahoma: University of Oklahoma.

Buchanan, Bruce (1974), "Building Organizational Commitment: The Socialization of Managers in Work Organizations", Administrative Science Quarterly, Vol. 19, No. 4: 533-546.

Bukhari, Imran; Kamal, Anila (2015), "Relationship between Perceived Organizational Politics and Its Negative Outcomes: Moderating Role of Perceived Organizational Support", Pakistan Journal of Psychological Research, Vol. 30: 271-288.

Byrne, Zinta S.; Hochwarter, Wayne A. (2008), “Perceived Organizational Support and Performance: Relationships across Levels of Organizational Cynicism", Journal of Managerial Psychology, Vol. 23, No. 1: 54-72. 


\section{Eskişehir Osmangazi Üniversitesi IïB Dergisi}

Caesens, G.; Stinglhamber, F. (2014), "The Relationship Between Perceived Organizational Support and Work Engagement: The Role of Self-Efficacy and Its Outcomes", Revue Européenne de Psychologie Appliquée, Vol. 64: 259267.

Cheung, Millissa F.Y.; Law, Monica C.C. (2008), "Relationships of Organizational Justice and Organizational Identification: The Mediating Effects of Perceived Organizational Support in Hong Kong", Asia Pacific Business Review, Vol. 14: 213-231.

Chiaburu, Dan S.; Peng, Ann Chunyan; Oh, In-Sue; Banks, George C.; Lomeli, Laura C. (2013), “Antecedents and Consequences of Employee Organizational Cynicism: A Meta-Analysis", Journal of Vocational Behavior, Vol. 83: 181197.

Cho, Jeewon; Treadway, Darren C. (2016), “Organizational Identification and Perceived Organizational Support As Mediators of the Procedural Justice-Citizenship Behaviour Relationship: A Cross-Cultural Constructive Replication", European Journal of Work and Organizational Psychology, Vol. 20, No. 5: 631-653.

Chughtai, Aamir Ali; Buckley, Finian (2009), "Linking Trust in The Principal to School Outcomes: The Mediating Role of Organizational Identification and Work Engagement", International Journal of Educational Management, Vol. 23: 574-589.

Cropanzano, Russell; Howes, John C.; Grandey, Alicia A.; Toth, Paul (1997), "The Relationship of Organizational Politics and Support to Work Behaviors, Attitudes, and Stress", Journal of Organizational Behavior, Vol. 18: 159-180.

Çakınberk, Arzu; Derin, Neslihan; Demirel, Erkan T. (2011), “Örgütsel Özdeşleşmenin Örgütsel Bağlılıkla Biçimlenmesi: Malatya ve Tunceli Özel Eğitim Kurumları Örneği”, İ̧sletme Araştırmaları Dergisi, Vol. 3, No. 1: 89-121.

Çelik, A.; Findik, M. (2012), "The Effect of Perceived Organizational Support on Organizational Identification", International Journal of Social, Behavioral, Educational, Economic, Business and Industrial Engineering, Vol. 6, No. 8: 2089-2094.

Dawley, David; Houghton, Jeffery D.; Bucklew, Neil S. (2010), “Perceived Organizational Support and Turnover Intention: The Mediating Effects of Personal Sacrifice and Job Fit", The Journal of Social Psychology, Vol. 150, No. 3: 238-257.

Dean, James W., Brandes, Pamela ve Dharwadkar, Ravi (1998), “Organizational Cynicism”, Academy of Management Review, Vol. 23, No. 2: 341-352.

Demistas, Ozgur; Hannah, Sean T.; Gok, Kubilay; Arslan, Aykut; Capar, Nejat (2015), "The Moderated Influence of Ethical Leadership, Via Meaningful Work, on Followers' Engagement, Organizational Identification, and Envy", Journal of Business Ethics, 1-17.

Dutton, Jane E.; Dukerich, Janet M.; Harquail, Celia V. (1994), “Organizational Images and Member Identification”, Administrative Science Quarterly, Vol. 39, 239-263.

Eisenberger Robert; Huntington, Robin; Hutchison Steven; Sowa, Debora (1986), "Perceived Organizational Support", Journal of Applied Pschology, Vol. 71, No. 3: 500-507.

Eisenberger, Robert; Fasolo, Peter; Davis-LaMastro, Valerie (1990), “Perceived Organizational Support and Employee Diligence, Commitment, and Innovation", Journal of Applied Psychology, Vol. 75, No. 1: 51-59.

Erkutlu, Hakan; Chafra, Jamel (2016), "Impact of Behavioral Integrity on Organizational Identification: The Moderating Roles of Power Distance and Organizational Politics", Management Research Review, Vol. 39, No. 6: 672-691.

Ertürk, Alper (2010), "Exploring Predictors of Organizational Identification: Moderating Role of Trust on The Associations Between Empowerment, Organizational Support and Identification", European Journal of Work and Organizational Psychology, Vol. 19, No. 4: 409-441.

Eryeşil, Kemalettin; Fındık, Mehtap (2011), "Örgütsel Sinizm”, Aykut Bedük (Ed.), Örgüt Psikolojisi: Yeni Yaklaşımlar, Güncel Konular (ss. 97-118) içinde. Konya: Atlas Akademi.

Evans, Nina; Qureshi, Mahmood Ahmed (2013), “Organisational Politics: The Impact on Trust, Information and Knowledge Management and Organisational Performance", European Conference on Information Management and Evaluation, 34-40.

Eyiusta, Ceyda Maden (2015), “iş̧görenlerin Güçlendirme Algılarının Sorumluluk Üstlenme Davranışları Üzerindeki Etkisi: İşe Adanmışlık ve İş Tatmini Değişkenlerinin Aracılık Rolü”, Dumlupınar Üniversitesi Sosyal Bilimler Dergisi, Vol. 43: 68-78.

Ferrer, Justine(2005), “Employee Engagement: Is It Organisational Commitment Renamed?”, Working Paper Series, 113. 
Ferris, Gerald R.; King, Thomas R. (1991), "Politics in Human Resources Decisions: A Walk on the Dark Side”, Organizational Dynamics, Vol. 20, No. 2: 59-71.

Ferris, Gerald R.; Fedor, Donald B.; Chachere, J. Gregory; Pondy, Louris R. (1989), "Myths and Politics in Organizational Contexts", Group \& Organization Studies, Vol. 14, No. 1: 83-103.

Gillet, Nicolas; Huart, Isabelle; Colombat, Philippe; Fouquereau, Evelyne (2013), "Perceived Organizational Support, Motivation, and Engagement Among Police Officers", Professional Psychology: Research and Practice, Vol. 44, No. 1: 46-55.

Gouldner, Alvin W. (1960), "The Norm of Reciprocity: A Preliminary Statement", American Sociological Review, Vol. 25, No. 2: 161-178.

Gözükara, İzlem; Şimşek, Ömer Faruk (2016), “Role of Leadership in Employees' Work Engagement: Organizational Identification and Job Autonomy", International Journal of Business and Management, Vol. 11, No. 1: 72-84.

Guarana, Cristiano Levi Oseliero (2010), The Moderator effect of Organizational Identification on the relationship between Work Context and Workforce Engagement/Burnout, (Yüksek Lisans Tezi), Ohio: The Ohio State University.

Gupta, Vishal; Agarwal, Upasna A; Khatri, Naresh (2016), "The Relationships Between Perceived Organizational Support, Affective Commitment, Psychological Contract Breach, Organizational Citizenship Behaviour and Work Engagement", Original Research: Empirical Research-Quantitative, 1-12.

Hall, Douglas T.; Schneider, Benjamin; Harold, T.N. (1970), "Personal Factors in Organizational Identification”, Administrative Science Quarterly, Vol. 15, No. 2: 176-190.

Harris, Ranida B.; Harris, Kenneth J.; Harvey, Paul (2007), "A Test of Competing Models of the Relationships Among Perceptions of Organizational Politics, Perceived Organizational Support and Individual Outcomes", The Journal of Social Psychology, Vol. 147, No. 6: 631-655.

He, Hongwei; Pham, Hung Quoc; Baruch, Yehuda; Zhu, Weichun (2014), “Perceived Organizational Support and Organizational Identification: Joint Moderating Effects of Employee Exchange Ideology and Employee Investment", The International Journal of Human Resource Management, Vol. 25, No. 20: 2772-2795.

He, Hongwei; Zhu, Weichun; Zheng, Xiaoming (2013), “Procedural Justice and Employee Engagement: Roles of Organizational Identification and Moral Identity Centrality", Journal of Business Ethics, Vol. 122: 681-695.

Hochwarter, Wayne A.; Kacmar, Charles; Perrewe, Pamela L.; Johnson, Diane (2003), "Perceived Organizational Support as a Mediator of The Relationship Between Politics Perceptions and Work Outcomes", Journal of Vocational Behavior, Vol. 63: 438-456.

İnce, Ali Rıza (2016), “Algılanan Örgütsel Desteğin İşe Adanmışlık Üzerindeki Etkisinde Yönetici Desteğinin Aracılık Rolü", Elektronik Sosyal Bilimler Dergisi, Vol. 15, No. 57: 649-660.

İşcan, Ömer Faruk (2005), "Siyasal Arena Metaforu Olarak Örgütler ve Örgütsel Siyasetin Örgütsel Adalet Algısına Etkisi", Ankara Üniversitesi SBF Dergisi, Vol. 60, No. 1: 149-171.

James Matrecia S. L. (2005), Antecedents and Consequences Of Cynicism In Organizations: An Examination of the Potential Positive and Negative Effects on School Systems, (Doktora Tezi), USA: The Florida State University.

Jin, Myung H.; McDonald, Bruce (2016), “Understanding Employee Engagement in the Public Sector: The Role of Immediate Supervisor, Perceived Organizational Support, and Learning Opportunities", American Review of Public Administration, 1-23.

Johnson, Jonathan L.; O'leary-Kelly, Anne M. (2003), "The Effects of Psychological Contract Breach and Organizational Cynicism: not all Social Exchange Violations are Created Equal”, Journal of Organizational Behavior, Vol. 24, No. 5: 627-647.

Karacaoğlu, Korhan; İnce, Fatma (2012), “Brandes, Dharwadkar ve Dean'in (1999) Örgütsel Sinizm Ölçeği Türkçe Formunun Geçerlilik ve Güvenilirlik Çalışması: Kayseri Organize Sanayi Bölgesi Örneği", Business and Economics Research Journal, Vol. 3, No. 2: 77-92.

Karanika-Murray, Maria; Duncan, Nikita; Pontes, Halley M.; Griffiths, Mark D. (2015), “Organizational Identification, Work Engagement and Job Satisfaction", Journal of Managerial Psychology, Vol. 30, No. 8: 1019-1033.

Karatepe, Osman M.; Aga, Mehmet (2016), "The Effects of Organization Mission Fulfillment and Perceived Organizational Support on Job Performance: The Mediating Role of Work Engagement", International Journal of Bank Marketing, Vol. 34, No. 3: 368-387. 


\section{Eskişehir Osmangazi Üniversitesi IïB Dergisi}

Kasalak, Gamze; Aksu, Mualla Bilgin (2014), "The Relationship between Perceived Organizational Support and Organizational Cynicism of Research Assistants", Educational Sciences: Theory \& Practice, Vol. 14, No. 1: 125-133.

Kim, Hong Min (2012), The Structural Relationships of Work Engagement With Its Antecedents and Consequences In The Korean Business Organization Context, (Doktora Tezi), Old Main: The Pennsylvania State University, The Department of Adult Education, Instructional Systems, and Workforce Education and Development.

Kurtessis, James N.; Eisenberger, Robert; Ford, Michael T.; Buffardi, Louis C.; Stewart, Kathleen A.; Adis, Cory S. (2015), "Perceived Organizational Support: A Meta-Analytic Evaluation of Organizational Support Theory", Journal of Management, Vol. XX, No. X: 1-31.

Landells, Erin; Albrecht, Simon L. (2013), “Organizational Political Climate: Shared Perceptions About the Building and Use of Power Bases", Human Resource Management Review, Vol. 23, 357-365.

Lee, Jaewon; Peccei, Riccardo (2011), "Discriminant Validity and Interaction Between Perceived Organizational Support and Perceptions of Organizational Politics: A Temporal Analysis", Journal of Occupational and Organizational Psychology, Vol. 84: 686-702.

Leiter, Michael P.; Bakker, Arnold B. (2010), “Work Engagement: Introduction”, A. B. Bakker ve M. P. Leiter (Ed.), Work Engagament: A Handbook of Essential Theory and Research (ss. 10-24) içinde. New York: Psychology Press.

Mael, Fred; Ashforth, Blake E. (1992), "Alumni and Their Alma Mater: A Partial Test of The Reformulated Model of Organizational Identification", Journal of Organizational Behavior, Vol. 13: 103-123.

Moideenkutty, Unnikammu; Blau, Gary; Kumar, Ravi; Nalakath, Ahamedali (2001), "Perceived Organisational Support as a Mediator of the Relationship of Perceived Situational Factors to Affective Organisational Commitment", Applied Psychology: An International Review, Vol. 50, No. 4: 615-634.

Nartgün, Şenay Sezgin; Kalay, Mustafa (2014), “Öğretmenlerin Örgütsel Destek, Örgütsel Özdeşleşme ile Örgütsel Sinizm Düzeylerine İlişkin Görüşleri”, Turkish Studies - International Periodical For The Languages, Literature and History of Turkish or Turkic, Vol. 9, No. 2: 1361-1376.

Ötken, Ayşe Begüm; Erben, Gül Selin (2010), “Investigating The Relationship Between Organizational Identification and Work Engagement and The Role of Supervisor Support", Gazi Üniversitesi Iktisadi ve Idari Bilimler Fakültesi Dergisi, Vol. 12, No. 2: 93-118.

Patchen, Martin (1970), Participation, Achievement, and Involvement on the Job, New Jersey: Prentice-Hall.

Polat, Mustafa; Meydan Cem Harun (2010), “Örgütsel Özdeşleşmenin Sinizm ve İşten Ayrılma Niyeti Ille İlişkisi Üzerine Bir Araştırma”, Savunma Bilimleri Dergisi, Vol. 9, No. 1: 145-172.

Randall, Marjorie L.; Cropanzano, Russell; Bormann, Carol A.; Birjulin, Andrej (1999), “Organizational Politics and Organizational Support as Predictors of Work Attitudes, Job Performance and Organizational Citizenship Behavior", Journal of Organizational Behavior, Vol. 20: 159-174.

Rich, Bruce L.; Lepine, Jeffrey A.; Crawford, Eean R. (2010), “Job Engagement: Antecedents and Effects on Job Performance", Academy of Management Journal, Vol. 53, No. 3: 617-635.

Saks, Alan M. (2006), "Antecedents and Consequences of Employee Engagement", Journal of Managerial Psychology, Vol. 21, No. 7: 600-619.

Schaufeli, Wilmar B.; Bakker, Arnold B. (2004), "Job Demands, Job Resources and Their Relationship With Burnout and Engagement: A Multi-Sample Study", Journal of Organizational Behavior, Vol. 25: 293-315.

Schaufeli, Wilmar B.; Bakker, Arnold B.; Salanova, Marisa (2006), "The Measurement of Work Engagement With a Short Questionnaire: A Cross-National Study", Educational and Psychological Measurement, Vol. 66, No. 4: 701716.

Schaufeli, Wilmar B.; Martinez, Isabel M.; Pinto, Alexandra Marques; Salanova, Marisa; Bakker, Arnold B. (2002), "Burnout and Engagement in Unıversity Students: A Cross-National Study", Journal of Cross-Cultural Psychology, Vol. 33, No. 5: 464-481.

Schaufeli, Wilmar B.; Salanova, Marisa; Gonzalez-Roma, Vicente; Bakker, Arnold B. (2002), "The Measurement of Engagement and Burnout: A Two Sample Confirmatory Factor Analytic Approach", Journal of Happiness Studies, Vol. 3: 71-92.

Shantz, Amanda; Alfes, Kerstin; Latham, Gary P. (2016), "The Buffering Effect of Perceived Organizational Support on the Relationship between Work Engagement and Behavioral Outcomes", Human Resource Management, Vol. 55, No. 1: 25-38. 
Shelton, Markus (2013), Impact of Perceived Organizational Support on Cyber Security Practitioners' Turnover Intentions, (Doktora Tezi), Minneapolis: Walden University, Applied Management and Decision Sciences Faculty.

Shen, Yimo; Jackson, Todd; Ding, Cody; Yuan, Denghua; Zhao, Lei; Dou, Yunlai; Zhang, Qinglin (2014), "Linking Perceived Organizational Support with Employee Work Outcomes in a Chinese Context: Organizational Identification as a Mediator", European Management Journal, Vol. 32: 406-412.

Shorbaji, Rania; Messarra, Leila; Karkoulian, Silva (2011), "Core-Self Evaluation: Predictor of Employee Engagement", The Business Review, Vol. 17, No. 1: 276-283.

Sides, Scott M. (2013), The Effect of Perceived Organizational Support and Perceived Organizational Politics on Teacher Commitment: An Analysis of Public and Non-Public Secondary Schools, (Doktora Tezi), Conway: University of Central Arkansas.

Sluss, David M.; Klimchak, Malayka; Holmes, Jeanne J. (2008), "Perceived Organizational Support as A Mediator Between Relational Exchange and Organizational Identification", Journal of Vocational Behavior, Vol. 73: 457464.

Sökmen, Alptekin; Ekmekçioğlu, Emre Burak; Çelik, Kamil (2015), “Algılanan Örgütsel Destek, Örgütsel Özdeşleşme ve Yönetici Etik Davranışı İlişkisi: Araştırma Görevlilerine Yönelik Araştırma”, İşletme Araştırmaları Dergisi, Vol. 7, No. 1: 125-144.

Taris, Toon W.; Schaufeli, Wilmar B.; Shimazu, Akihito (2010), "The Push and Pull of Work: The Differences Between Workaholism and Work Engagement", Workaholism and Work Engagement, 39-53.

Tokgöz, Nuray (2011), "Örgütsel Sinisizm, Örgütsel Destek ve Örgütsel Adalet illişkisi: Elektrik Dağıtım İşletmesi Çalışanları Örneği”, Eskişehir Osmangazi Üniversitesi IiBF Dergisi, Vol. 6, No. 2: 363-387.

Tokgöz, Nuray; Yılmaz, Hakan (2008), "Örgütsel Sinisizm: Eskişehir ve Alanya'daki Otel İşletmelerinde Bir Uygulama”, Anadolu Üniversitesi Sosyal Bilimler Dergisi, Vol. 8, No. 2: 283-305.

Treadway, Darren C.; Hochwarter, Wayne A.; Ferris, Gerald R.; Kacmar, Charles J.; Douglas, Ceasar; Ammeter, Anthony P.; Buckley, M. Ronald (2004), "Leader Political Skill and Employee Reactions", The Leadership Quarterly, Vol. 15, No. 4: 493-513.

Turunç, Ömer; Çelik, Mazlum (2010), "Çalışanların Algıladıkları Örgütsel Destek ve İş Stresinin Örgütsel Özdeşleşme ve İş Performansına Etkisi”, Yönetim ve Ekonomi, Vol. 17, No. 2: 183-206.

Türkiye Bankalar Birliği. Türkiye'de Bankacılık Sistemi Seçilmiş Göstergelerin İllere ve Bölgelere Göre Dağılımı. Haziran 2016.

van Knippenberg, Daan; Dick, Rolf Van; Tavares, Susana (2007), "Social Identity and Social Exchange: Identification, Support and Withdrawal From the Job", Journal of Applied Social Psychology, Vol. 37, No. 3: 457-477.

Vigoda, Eran; Cohen, Aaron (2002), "Influence Tactics and Perceptions of Organizational Politics: A Longitudinal Study", Journal of Business Research, Vol. 55: 311-324.

Wann-Yih, Wu; Htaik, Sein (2011), "The Impacts of Perceived Organizational Support, Job Satisfaction and Organizational Commitment on Job Performance in Hotel Industry", The 11th International DSI and the 16th APDSI Joint Meeting, July 12-16 2011, Taiwan.

Zagenczyk, Thomas J.; Gibney, Ray; Few, W. Timothy; Scott, Kristin L. (2011), "Psychological Contracts and Organizational Identification: The Mediating Effect of Perceived Organizational Support", Journal of Labor Research, Vol. 32: 254-281. 
Eskişehir Osmangazi Üniversitesi IißBF Dergisi 